\title{
Cytological maps of lampbrush chromosomes of European water frogs (Pelophylax esculentus complex) from the Eastern Ukraine
}

Dmitry Dedukh', Glib Mazepa ${ }^{2,3}$, Dmitry Shabanov ${ }^{3}$, Juriy Rosanov ${ }^{4}$, Spartak Litvinchuk ${ }^{4}$, Leo Borkin ${ }^{5}$, Alsu Saifitdinova ${ }^{1}$ and Alla Krasikova ${ }^{1 *}$

\begin{abstract}
Background: Hybridogenesis (hemiclonal inheritance) is a kind of clonal reproduction in which hybrids between parental species are reproduced by crossing with one of the parental species. European water frogs (Pelophylax esculentus complex) represent an appropriate model for studying interspecies hybridization, processes of hemiclonal inheritance and polyploidization. P. esculentus complex consists of two parental species, P. ridibundus (the lake frog) and $P$. lessonae (the pool frog), and their hybridogenetic hybrid - P. esculentus (the edible frog). Parental and hybrid frogs can reproduce syntopically and form hemiclonal population systems. For studying mechanisms underlying the maintenance of water frog population systems it is required to characterize the karyotypes transmitted in gametes of parental and different hybrid animals of both sexes.
\end{abstract}

Results: In order to obtain an instrument for characterization of oocyte karyotypes in hybrid female frogs, we constructed cytological maps of lampbrush chromosomes from oocytes of both parental species originating in Eastern Ukraine. We further identified certain molecular components of chromosomal marker structures and mapped coilin-rich spheres and granules, chromosome associated nucleoli and special loops accumulating splicing factors. We recorded the dissimilarities between P. ridibundus and P. lessonae lampbrush chromosomes in the length of orthologous chromosomes, number and location of marker structures and interstitial (TTAGGG) -repeat sites as well as activity of nucleolus organizer. Satellite repeat RrS1 was mapped in centromere regions of lampbrush chromosomes of the both species. Additionally, we discovered transcripts of RrS1 repeat in oocytes of P. ridibundus and P. lessonae. Moreover, G-rich transcripts of telomere repeat were revealed in association with terminal regions of $P$. ridibundus and $P$. lessonae lampbrush chromosomes.

Conclusions: The constructed cytological maps of lampbrush chromosomes of $P$. ridibundus and $P$. lessonae provide basis to define the type of genome transmitted within individual oocytes of $P$. esculentus females with different ploidy and from various population systems.

Keywords: Centromere, Chromosome, European water frog, Hybridization, Karyotype, Non-coding RNA, Nuclear body, Oocyte, Telomere

\footnotetext{
* Correspondence: alla.krasikova@gmail.com

${ }^{1}$ Saint-Petersburg State University, Oranienbaumskoie sch. 2, Stary Peterhof, Saint-Petersburg 198504, Russia

Full list of author information is available at the end of the article
} 


\section{Background}

Interspecies hybridization is spread rather widely across different groups of living organisms though offspring of such mating are often sterile. Hybrid sterility reduces the exchange of genes between two species ensuring species divergence [1]. Nevertheless hybridization produces new gene combinations making hybrids more successful in evolution. Resolving the problems of fertilization and reproductive isolation from parental species can lead to appearance of new species in prospect [2-5]. Reproducibility of the majority of natural interspecies hybrids in vertebrates can be achieved in clonal ways of reproduction which are often accompanied by polyploidy: parthenogenesis (occurring in some fishes, lizards, and snakes), gynogenesis (ambystomes and some fishes), and hemiclonal inheritance (frogs, toads and some fishes).

The European water frogs of the Pelophylax esculentus complex represent an appropriate model for studying interspecies hybridization accompanied by hemiclonal inheritance and polyploidization (reviewed in [6]). This complex consists of two parental species - the lake frog Pelophylax ridibundus (genome composition RR) and the pool frog $P$. lessonae (LL), as well as natural hybridogenetic form the edible frog P. esculentus (LR), the latter arising as a result of hybridization between the two parental species [7]. In the generations of hybrid frogs, the phenomenon of hemiclonal inheritance was registered: one of two genomes is eliminated from the germline, while the other (clonal genome) can be transmitted to gametes without recombination $[6,8]$. If hybrid males and females transmit identical clonal genomes, crossing between the two hybrids results in appearance of corresponding parental species. Parental individuals appearing in such a way often have developmental deviations and die before maturity (reviewed in [6]). Such problems in individual development of parental animals can be explained by accumulation of negative recessive mutations, which can not be removed from the clonal genome due to lack of recombination [6]. All these forms compose hemiclonal population systems, where $P$. esculentus transmit either $\mathrm{L}$ or $\mathrm{R}$ genome as a clonal one. The type of transmitted genome is correlated with parental species syntopic with hybrid frogs. In population systems, hybrid frogs can be represented not only by diploid animals but also by triploids with genotypes LLR and RRL. These latter forms most likely appear as a result of fertilization of egg cell with two sets of chromosomes by haploid sperm or vise versa [9].

Although hybridogenetic diploid frogs (P. esculentus) are widely known across temperate Europe from France in the west to Volga River in the east [6,10], natural polyploidy has been found in population systems distributed in western and central parts of Europe only [6]. The Seversky Donets River basin (Eastern Ukraine) is also inhabited by polyploids of $P$. esculentus [11]. The local population systems of water frogs include $P$. ridibundus, diploid $P$. esculentus, two forms of triploid P. esculentus, and even rare tetraploid $P$. esculentus (with LLRR genotype). Diploid hybridogenetic males in this region transmit clonally $P$. lessonae or P. ridibundus genomes, or both genomes in different gametes [11]. In some population systems of the basin, triploid hybrid frogs reached the majority of individuals. At the same time, water frog population systems found in the Seversky Donets River basin have some distinctive features from other hybrid formation centers. The first one is the isolation of the Seversky Donets River basin population system from European centers that produce triploid hybrid frogs approximately to the distances of $1000 \mathrm{~km}$ (eastern Poland) and $1500 \mathrm{~km}$ (western Hungary) [11]. The second one is the reproduction of hybrid frogs without $P$. lessonae since only several immature individuals were found in some local population systems [11-13]. In our present and future studies, the Seversky Donets River basin was chosen as main center for understanding the mechanisms of interspecies hybridization in European water frogs.

For studying mechanisms underlying the maintenance and dynamics of water frog populations, a cytogenetic analysis of karyotypes transmitted in gametes of parental and various hybrid animals of both sexes is required. The number of chromosomes in spermatocytes of $P$. esculentus can be estimated by examination of squash testis preparations and in drop preparations. Nevertheless, the main problem of definition the parental chromosomes in hybrid gametes is identical number and morphological resemblance of orthologous chromosomes in karyotypes of parental species [14-17]. DNA-flow cytometry approach resolves this problem and was successfully applied to identify the genome composition of male gametes in both parental species and hybrid frogs of $P$. esculentus complex from various population systems of the Eastern Ukraine [12]. However, genome composition in female gametes of water frogs from this region has never been previously determined. The original approach, which allows to estimate the chromosomal number in growing oocytes and to define the species-specific features of chromosomal morphology, is examination of giant lampbrush chromosomes microsurgically isolated from oocyte nucleus. This method was suggested and widely used in the pioneering studies of amphibian oocyte karyotypes (for a review, see $[18,19]$ ).

Lampbrush chromosomes are a form of meiotic chromosomes occurring in growing oocytes of many animals during the long diplotene period of prophase I of meiosis. Lampbrush chromosomes exist as highly extended halfbivalents with homologous chromosomes connected by chiasmata. They are characterized by distinctive chromomere-loop structure, and comprise conspicuous lateral loops, corresponding to trancriptionally active regions, 
and chromomeres that consist of inactive chromatin segments [18,20-23].

For the first time lampbrush chromosomes of the Pelophylax esculentus complex were described in 1979 [24], but only a decade later Bucci et al. [16] characterized lampbrush chromosomes of $P$. ridibundus and $P$. lessonae from Poland in detail. They also suggested that described lampbrush karyoptypes can be used for genome identification in oocytes derived from hybrid frogs, $P$. esculentus $[16,25]$. Lampbrush chromosomes of European water frogs are quite long (up to $500 \mu \mathrm{m}$ in length), which correlates with the average size of their genomes (14.0-16.4 pg for a diploid genome; $[11,26])$. Like lampbrush chromosomes of many other amphibian and avian species, lampbrush chromosomes of European water frogs bear a variety of marker structures including loops with unusual morphology and complex organization, associated spherical bodies, and nucleoli, which altogether allow the identification of all individual chromosomes [16].

In this paper we perform a detailed analysis of oocyte karyotypes of $P$. ridibunda and $P$. lessonae originating from Eastern Ukraine and present comprehensive cytological maps of all parental lampbrush chromosomes of the European water frog complex, describing intraspecific variation between frogs from Ukrainian and Polish populations. We also characterize molecular composition of marker structures that distinguish orthologous lampbrush chromosomes of the parental species. Furthermore, we provide evidences for transcription of tandem repeats in centromere and telomere regions of chromosomes during the lampbrush stage of oogenesis in European water frogs.

\section{Results}

In this work we first aimed to determine morphologically distinctive marker structures on lampbrush chromosomes of two parental species (the lake frog and the pool frog) of the European water frogs originating from Eastern Ukraine. For that purpose we analyzed and statistically treated data for 11 full sets of lampbrush chromosomes from P. ridibundus females and 10 preparations with full sets of lampbrush bivalents from $P$. lessonae females. Additional preparations of nuclear contents from $7 P$. ridibundus oocytes and 6 P. lessonae oocytes were used for FISH and immunofluorescent staining procedures. The species assignment of all individuals was performed by genome size measurement using DNA flow cytometry. Individuals with C-values between 15.99 and 16.22 were referred to $P$. ridibundus species and individuals with $\mathrm{C}$-values between 14.01 and 14.15 were considered as P. lessonae species according to Borkin and coauthors [11]. All oocytes examined had normal chromosomal number of 13 bivalents in each set. 5 large and 8 small bivalents were discerned in $P$. ridibundus and $P$. lessonae lampbrush karyotypes (Figure 1 and Additional file 1: Figure S1).
The relative chromosome sizes (chromosomal length relatively the longest one) of all lampbrush chromosomes in each karyotype were estimated (Tables 1 and 2), that allowed to define them by letters from $\mathrm{A}$ to $\mathrm{M}$ in the following description (Figure 1 and Additional file 1: Figure S1). For each chromosome of the both species the centromere index (ratio of the short arm length to the total chromosome length) was calculated (Tables 1 and 2). The estimated average number of chiasmata in a set of bivalents from lampbrush stage oocytes was $51.94 \pm 1.37$ for P. lessonae $(\mathrm{n}=16)$ and $59.83 \pm 1.73$ for $P$. ridibundus $(\mathrm{n}=18)$. Chiasmata frequency of $P$. ridibundus significantly differed from chiasmata frequency of $P$. lessonae (Student's t-test, $\mathrm{p}<0.001$ ).

Morphological analysis revealed following regularly identifiable longitudinal landmarks on lampbrush chromosomes: centromeres, terminal and interstitial granules, complex lumpy loops with dense RNP-matrix, long marker loops, giant loops with dense RNP-matrix, and chromosome associated spheres and nucleoli (Tables 1 and 2). It should be stressed that during the lampbrush chromosome stage of oogenesis, thousands of extrachromosomal bodies, such as amplified nucleoli, spheres, B-snurposomes, appear in the nucleus of growing amphibian oocyte and can be observed on spread preparations (Figure 1) [22].

Immunofluorescent staining allowed to sort marker structures that have distinct morphological appearance and to identify additional marker loops on lampbrush chromosomes of both species. Antibodies K121 against 2,2,7trimethylguanosine (TMG) cap of most of the small nuclear RNAs (snRNAs) and mAb Y12 against symmetrical dimethylarginine allowed to identify marker loops, accumulating spliceosomal components (Figures 2a, f, Additional file 1: Figure S1). Example of lumpy loops enriched with snRNPs is shown on Figure 2f. These mAbs also stained extrachromosomal nuclear organelles (Figure 2a, Additional file 1: Figure S1), which in Xenopus oocytes were referred as B-snurposomes and spheres [23]. Immunostaining with antibodies against nucleolar proteins Nopp-140, No38 and fibrillarin was aimed to detect nucleoli associated with lampbrush chromosomes (Figure 2c). It is important to note that these proteins also concentrate in multiple extrachromosomal nucleoli (Figure 2c). Antibodies against coilin were applied to nuclear contents preparations in order to reveal coilin-positive bodies and chromosome associated granules (Figure 2g).

\section{Construction of cytological lampbrush chromosome maps}

Detailed cytological maps of lampbrush chromosomes of two water frog species were constructed on the basis of statistical treatment of data from lampbrush chromosome micrographs. On these maps, relative positions of various marker structures were plotted. For example, lampbrush chromosome $\mathrm{H}(\mathrm{LBC} H)$ of $P$. ridibundus bears all 


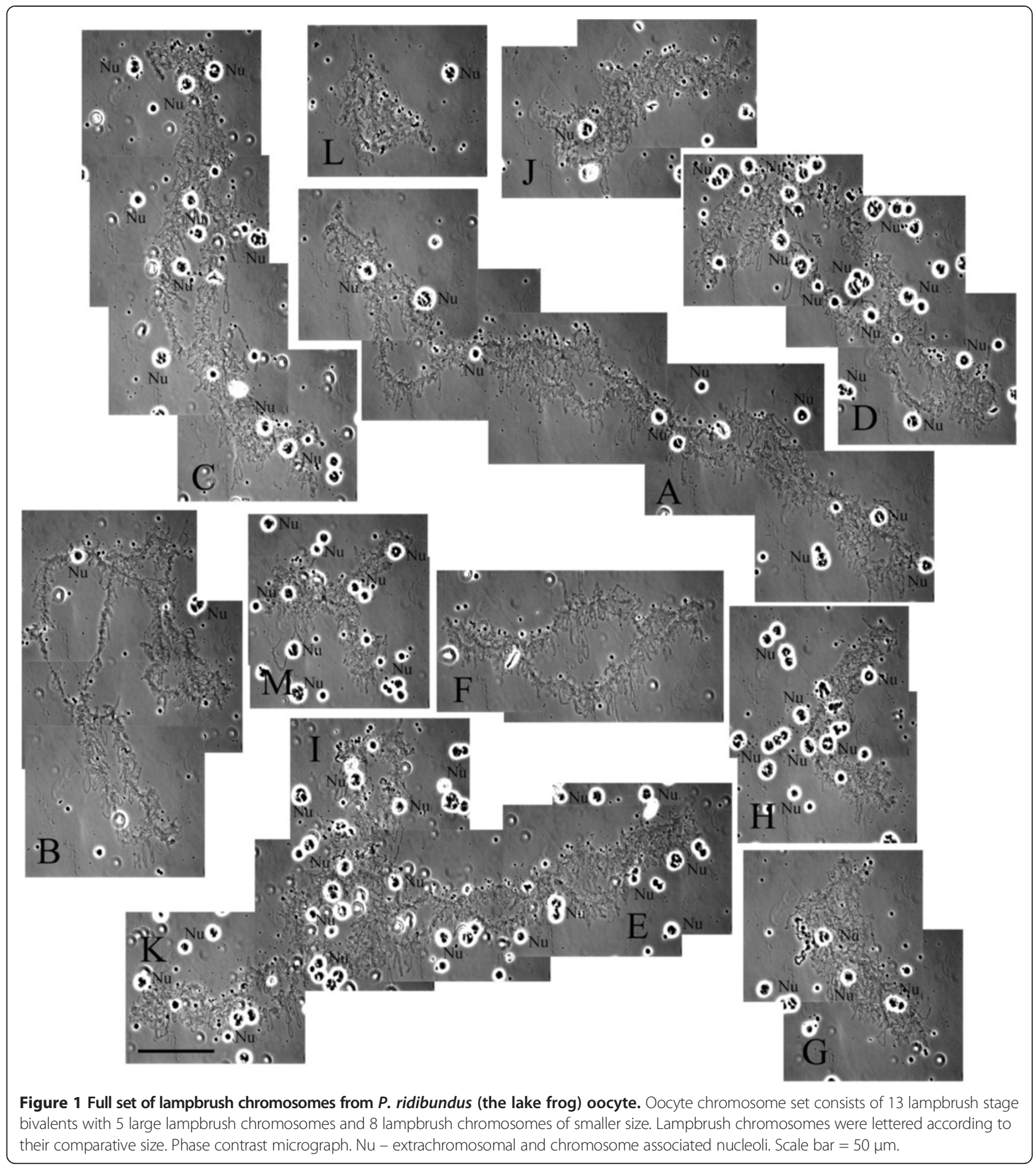

specified marker structures except for spheres (Table 1 and Additional file 2: Figure S2b), which were pointed out on corresponding cytological map of this lampbrush chromosome (Additional file 2: Figure S2a). It is worth mentioning that the average size of giant loops on LBC H was estimated as $12 \mu \mathrm{m}$; usually giant loops formed by sister chromatids were found fused together (Additional file 2: Figure
S2b). Landmark structures that contain some of the identified molecular components were marked by different colors on cytological maps (Figures 2b, e). As can be seen from example of the $P$. ridibundus $\mathrm{LBC} \mathrm{H}$, the immunofluorescence assay with antibodies K121 against TMG-cap of small nuclear RNA revealed marker loops accumulating spliceosomal components (Figure 2a). One can easily 
Table 1 Relative length and positions of marker structures on lampbrush chromosomes of $P$. ridibundus

\begin{tabular}{|c|c|c|c|c|c|c|c|c|}
\hline № & Relative length & Centromere index & Long marker loops & Lumpy loops & Giant structure & Nucleolus & Spheres & Large granules \\
\hline $\bar{A}$ & 100 & 43.5 & $2 ; 37 ; 99$ & & & & & 78 \\
\hline B & 87.1 & 30.88 & $19.7 ; 41.1$ & 25.49 & & & 97.5 & \\
\hline C & 70 & 29.71 & 77.57 & 83.29 & & & & \\
\hline$D$ & 62.1 & 22.12 & $0 ; 31.88$ & 29.31 & & & & 20.29 \\
\hline E & 56 & 41.61 & & 34.64 & & & & \\
\hline $\mathrm{F}$ & 43.6 & 38.53 & 53.9 & & & & & \\
\hline G & 38.5 & 44.16 & $11.69 ; 55.58 ; 67.53$ & & & & & \\
\hline $\mathrm{H}$ & 35.8 & 32.68 & $56.7 ; 69.27$ & & 39.11 & 62.29 & & \\
\hline । & 31.4 & 40.76 & $32.8 ; 62.78 ; 72.61$ & & & & & \\
\hline J & 29.9 & 10.7 & 51.84 & $33.44 ; 64.88$ & & & & \\
\hline K & 29.2 & 15.41 & 21.58 & 34.93 & & & 11.3 & \\
\hline L & 23.4 & 27.78 & 44.02 & 60.68 & & & & \\
\hline M & 20.1 & 27.36 & 41.29 & & & & & \\
\hline
\end{tabular}

identify these loops on lampbrush chromosome spreads by brilliant staining. Immunostaining with antibodies against nucleolus protein Nopp-140 showed presence of one nucleolus of approximately $10 \mu \mathrm{m}$ in diameter in association with the nucleolus organizing region (NOR) on $\mathrm{LBC} \mathrm{H}$ (Figure 2c). Using fluorescence in situ hybridization (FISH) we located pericentromeric satellite $\mathrm{RrS1}$ repeat, which was first identified by Ragghianti and coauthors [27], in $P$. ridibundus and P. lessonae from Poland. Furthermore, FISH with oligonucleotide probe specific to (TTAGGG) repeat in its turn allowed to mark interstitial blocks of this repeat or sequences containing TTAGGG repeat on constructed map of LBC H (Figure 2d). Using antibodies against coilin we distinguished and marked on the LBC H map coilin-positive granules, which were found not only in telomere regions, but also in interstitial sites corresponding to chromomeres containing (TTAGGG) $\mathrm{n}$ repeat
(Figure 2g). Cytological maps of other lampbrush chromosomes were constructed in the same way.

The results of detailed characterization of lampbrush chromosomes of $P$. ridibundus and $P$. lessonae as well as comparative analysis of the orthologs with special emphasize on difference between sets of marker structures are presented below.

\section{Comparison of $\mathrm{P}$. ridibundus and $\mathrm{P}$. lessonae lampbrush chromosome $A$}

In karyotypes of both species, chromosome $\mathrm{A}$ is the longest chromosome at the lampbrush stage (Tables 1 and 2). It is characterized by presence of several landmark structures namely lateral loops with special morphology and composition. In subtelomeric regions of the long and the short arms of LBC A of both species, we identified noticeable marker loops that do not differ from simple lateral loops in terms of

Table 2 Relative length and positions of marker structures on lampbrush chromosomes of $\boldsymbol{P}$. lessonae

\begin{tabular}{|c|c|c|c|c|c|c|c|c|}
\hline № & Relative length & Centromere index & Long marker loops & Lumpy loops & Giant structure & Nucleolus & Spheres & Large granules \\
\hline A & 100 & 39.1 & $1.1 ; 15.8 ; 97.5$ & & & & & $88.4 ; 98.1$ \\
\hline B & 83.8 & 34.37 & $54.3 ; 84.61 ; 93$ & 37.95 & & & 96.78 & \\
\hline$C$ & 75.9 & 37.9 & $19.5 ; 35.44 ; 69.57$ & 43.35 & & & & $0 ; 82.74$ \\
\hline $\mathrm{D}$ & 68.4 & 23.68 & 72.95 & $29.39 ; 85.09$ & & & & 75.73 \\
\hline $\mathrm{E}$ & 61 & 41.31 & $0 ; 19.18$ & $30.16 ; 45.57 ; 48.52$ & & & & 0 \\
\hline $\mathrm{F}$ & 45 & 39.6 & 58.44 & 35.33 & & & & \\
\hline G & 40.1 & 41.9 & & $36.41 ; 53.12 ; 71.82$ & & & & \\
\hline $\mathrm{H}$ & 35.7 & 36.69 & 59.94 & 47.9 & & & & \\
\hline I & 34.5 & 7.3 & 50.72 & & & & & \\
\hline J & 33.4 & 16.47 & $0 ; 23.35$ & 39.52 & & & 13.77 & \\
\hline K & 28.1 & 23.13 & & 38.43 & & & & \\
\hline L & 26 & 45.77 & 83.08 & 66.92 & & & 32.69 & \\
\hline M & 21.9 & 26.48 & 47.03 & $35.16 ; 67.12$ & & & & \\
\hline
\end{tabular}




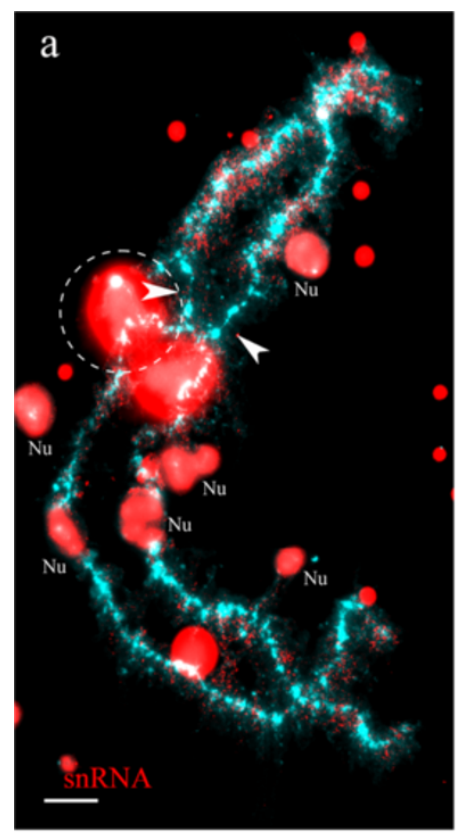

b

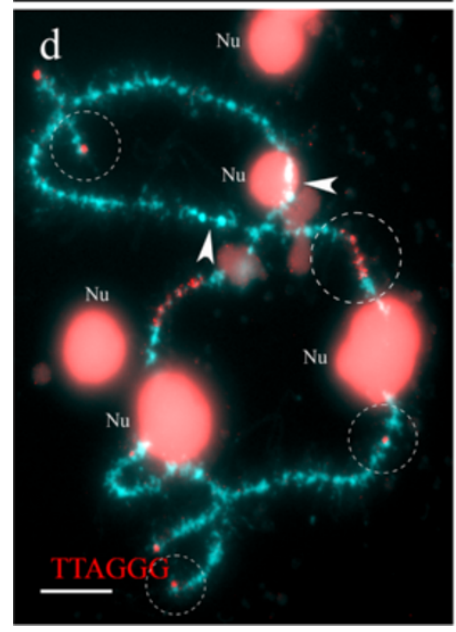

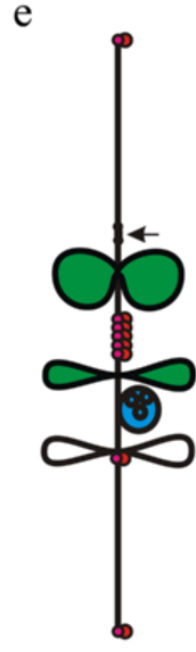
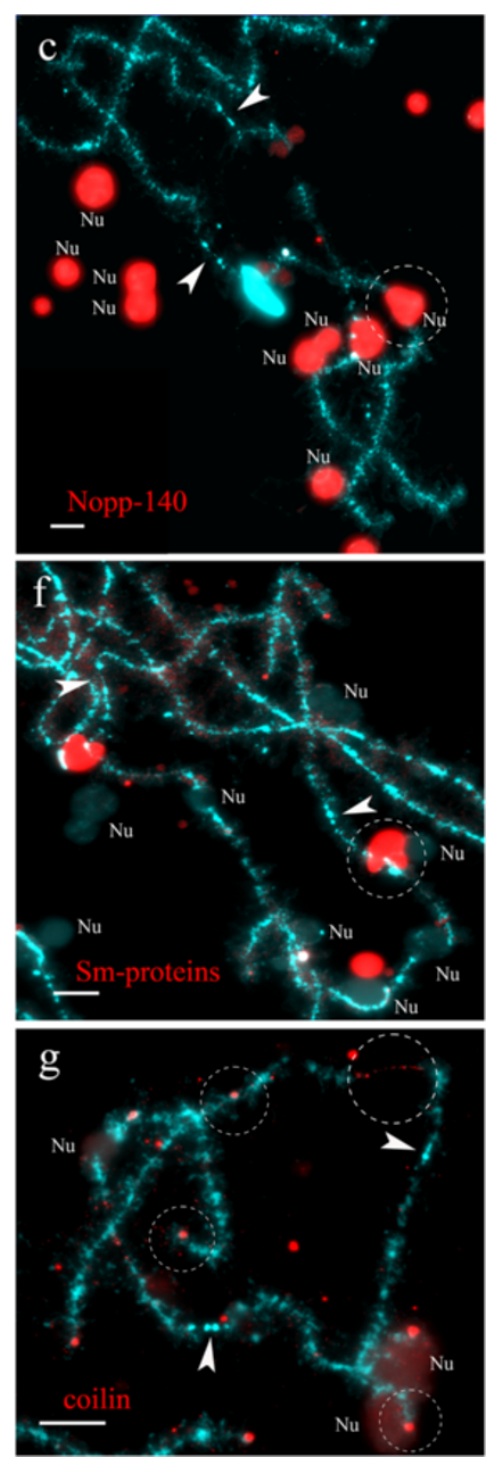

Figure 2 Immunodetection of components of landmark structures and FISH mapping of (TTAGGG)-repeat sites on lampbrush chromosome $\mathbf{H}$ of $\boldsymbol{P}$. ridibundus (the lake frog). $\mathbf{a}, \mathbf{f}$. Identification of giant structures (giant fusing loops) and marker loops enriched with splicing factors. Immunofluorescent staining with antibodies K121 against TMG-cap of snRNA (a) and antibodies Y12 against Sm-proteins (f). c. Identification of chromosome associated nucleolus using immunofluorescent staining with antibodies No-185 against nucleolus protein Nopp-140. Dotted lines indicate marker structures. $\mathbf{d}$. FISH mapping of (TTAGGG) repeat on lampbrush chromosome H. Telomeres and interstitial (TTAGGG)repeat sites were detected and shown by dotted lines. $\mathbf{g}$. Detection of coilin-positive granules (indicated by dotted lines) by immunofluorescent staining with R288 antibody. Arrowheads show centromeres. Nu - extrachromosomal nucleoli. Chromosomes are counterstained with DAPI. Scale bars $=10 \mu \mathrm{m}$. b. e. Color indication of marker structures according to their molecular components on cytological map of lampbrush chromosome H. Loops accumulating splicing factors are colored green, chromosome associated nucleolus - blue, coilin accumulating granules - red.

concentration of snRNPs (Figures 1, 3 and Additional file 1: Figure S1). These loops extend to $10 \mu \mathrm{m}$ in length being 1.5 times longer than the vast majority of simple lateral loops. The lampbrush chromosome A of $P$. lessonae bears a marker loop in its short arm, which accumulates splicing factors (Figure $3 \mathrm{~b}$ ). This loop was not recognizable in the orthologous lampbrush chromosome of $P$. ridibundus. Instead, the chromosome A of the latter bears another pair of marker loops on the short arm not far from centromeric region (Figures 1, 3a and Additional file 1: Figure S1). This particular marker loop does not accumulate splicing factors but is characterized by unusual morphology of RNP-matrix. On the majority of preparations, distinctive chromomeres were found in the long arm of LBC A (Figures 1, 3a, b and Additional file 1: Figure S1). These chromomeres occupy slightly different positions in corresponding lampbrush chromosomes of both species. In addition, chromosome A of $P$. ridibundus sometimes has a large chromomere in 


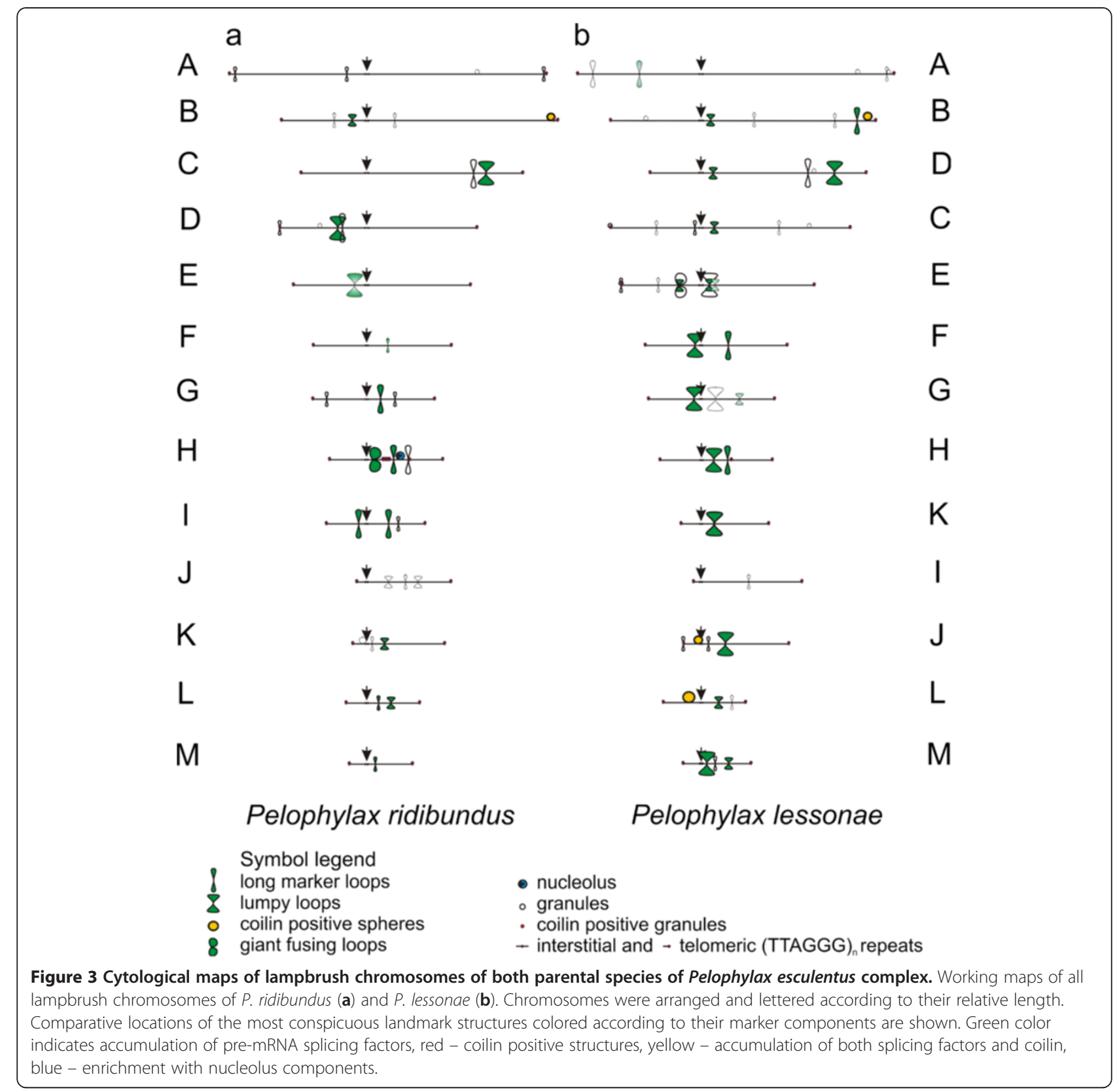

subtelomeric region. In our opinion, distinctive chromomeres are not reliable for identification of lampbrush chromosome A, since they are not always present in their usual positions.

\section{Comparison of $\mathrm{P}$. ridibundus and $\mathrm{P}$. lessonae lampbrush chromosome $B$}

In both species, the long arm of chromosome B has a sphere in its subtelomeric region, which contains premRNA splicing factors and protein coilin (Figures 4a, b, c, $\mathrm{e}, \mathrm{f})$. There is an interstitial block of (TTAGGG) $\mathrm{n}$ repeat or sequences containing (TTAGGG) $\mathrm{n}$ repeat near this sphere in $P$. ridibundus but not $P$. lessonae lampbrush chromosome B (Figures 4d, d`, 3a, b). Another distinctive feature of $P$. lessonae LBC B is a pair of long marker loops containing pre-mRNA splicing factors in its long arm (Figures 4e, f, 3b). Notably, there are no loops in the same locus of the $P$. ridibundus lampbrush chromosome B. We have also registered appearance of distinctive chromomere in the short arm of P. lessonae LBC B on the majority of preparations.

\section{Comparison of $\mathrm{P}$. ridibundus lampbrush chromosome $\mathrm{C}$} and $\mathrm{P}$. lessonae lampbrush chromosome $D$

Lampbrush chromosome $\mathrm{C}$ of $\mathrm{P}$. ridibundus and chromosome $\mathrm{D}$ of $P$. lessonae differ in their comparative length, 

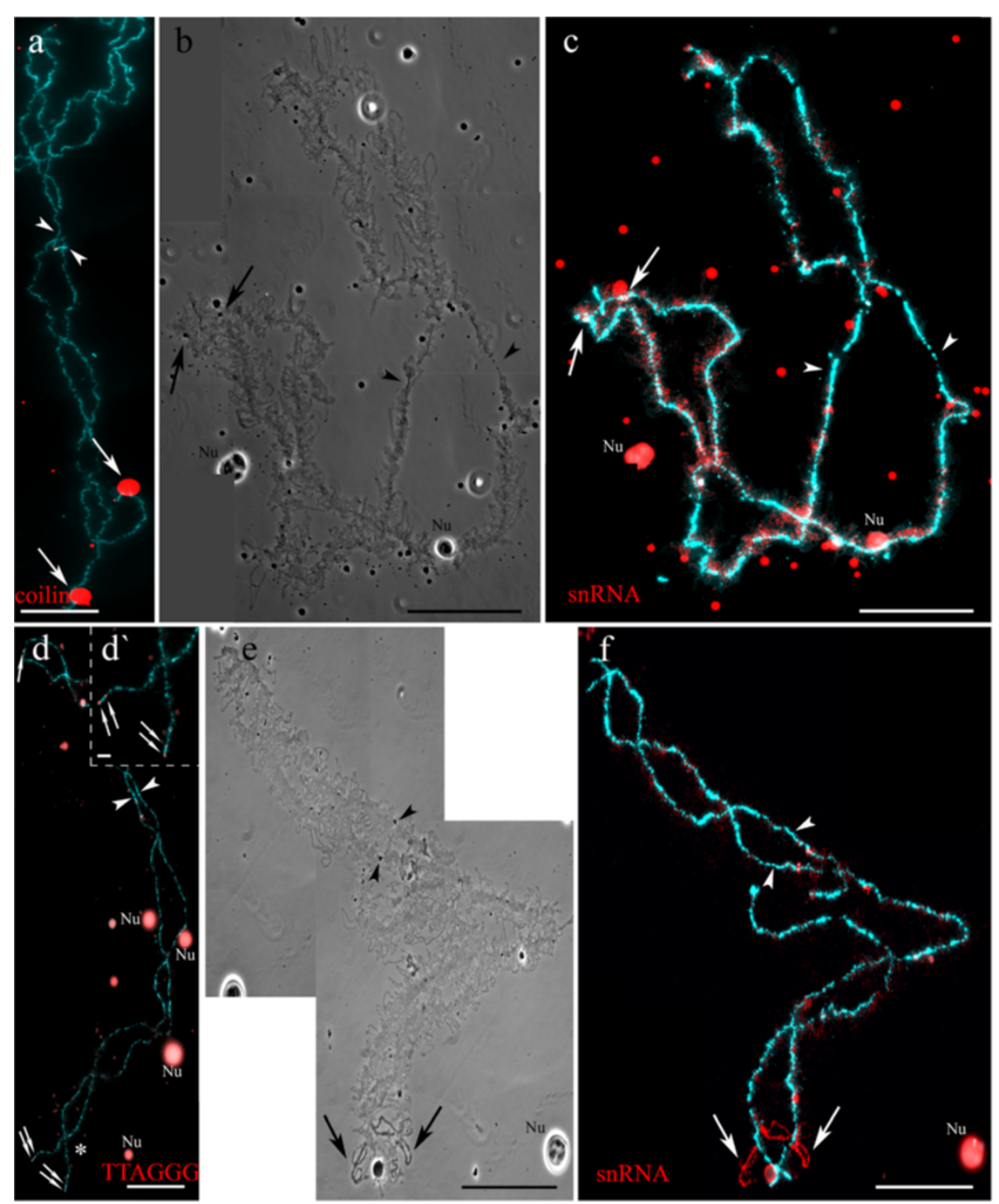

Figure 4 Comparison of $P$. ridibundus $\left(a, b, c, d, d^{\prime}\right)$ and $P$. lessonae $(e, f)$ lampbrush chromosome $B$. Phase contrast micrographs $(b, e)$, immunofluorescent staining with antibodies against coilin (a), TMG-cap of $\operatorname{snRNAs}(\mathbf{c}, \mathbf{f})$. Sites with mapped (TTAGGG) $n$ repeat (d) are indicated by arrows. Spheres (shown by arrows) in subtelomeric region of the long arm of $P$. ridibundus lampbrush chromosome B (a, b, c). Long marker loops (shown by arrows) (e, $\mathbf{f}$ ) close to sphere loci in the long arm of $P$. lessonae lampbrush chromosome B. Chromosomes are counterstained with DAPI. Nu - extrachromosomal nucleoli. Arrowheads show centromeres. Scale bars $=50 \mu \mathrm{m}$. Asterisks indicate enlarged fragment of lampbrush chromosome B with mapped (TTAGGG) $n$ repeat (d). Arrows indicates telomeric and interstitial blocks of sequences containing (TTAGGG) $n$ repeat in a subtelomeric region of the long arm of $P$. ridibundus lampbrush chromosome B (d'). Scale bars $=10 \mu \mathrm{m}$.

but have almost identical centromeric index and similar pattern of marker structures (Additional file 3: Figures S3a, b, c, d). Both lampbrush chromosomes contain marker loop, which does not accumulate splicing factors, and a conspicuous lumpy loop enriched with spliceosomal snRNPs (Figures 3a, b). Distance between these loops is slightly different being longer in $P$. lessonae. On some preparations, a large chromomere can localize between mentioned loops in LBC D of $P$. lessonae. In addition, a smaller lumpy loop accumulating splicing factors is situated near centromeric region in the long arm of $P$. lessonae lampbrush chromosome $\mathrm{D}$ but not in $P$. ridibundus lampbrush chromosome C (Additional file 3: Figures S3a, b, c, d).

\section{Comparison of $\mathrm{P}$. ridibundus lampbrush chromosome $D$ and $\mathrm{P}$. lessonae lampbrush chromosome $\mathrm{C}$}

Lampbrush chromosome $\mathrm{D}$ of $P$. ridibundus is similar to chromosome $\mathrm{C}$ of $P$. lessonae according to its centromeric index (Tables 1 and 2). Nevertheless they have a lot of dissimilarities in overall structure, type of marker loops and their arrangement (Additional file 3: Figures S3e, f, g, h). In 
the short arm of lampbrush chromosome $\mathrm{D}$ of $P$. ridibundus, there are lumpy loops accumulating snRNPs and long marker loops that do not concentrate them. Another set of long marker loops without enrichment in splicing factors was also found in terminal region of the short arm of chromosome D in this species (Additional file 3: Figures S3e, f). Large chromomere is located in the short arm of $P$. ridibundus chromosome $\mathrm{D}$ on the majority of lampbrush chromosome preparations. Lampbrush chromosome $\mathrm{C}$ of $P$. lessonae contains a terminal granule and marker loops that do not accumulate spliceosomal components in the short arm near the centromere. In addition, lumpy loops containing splicing factors form not far from centromere in the long arm of LBC $\mathrm{C}$ of $P$. lessonae (Additional file 3: Figures S3g, h).

\section{Comparison of $\mathrm{P}$. ridibundus and $\mathrm{P}$. lessonae lampbrush chromosome $E$}

There are a few marker structures on lampbrush chromosome $\mathrm{E}$ of $P$. ridibundus: only in several lampbrush chromosome spreads, we observed lumpy loops accumulating splicing factors in the short arm (Table 1 and Figure 3a). Similarly, lampbrush chromosome $\mathrm{E}$ of $P$. lessonae has a pair of lumpy loops with splicing factors in its short arm, although there are a prominent granule and a pair of marker loops in the terminal region of the short arm (Table 2 and Figure 3b). We also identified lumpy loops containing pre-mRNA splicing factors that appear in the long arm near the centromere in the $P$. lessonae lampbrush chromosome E (Figure 3b). All lumpy loops reached giant size in three lampbrush chromosome spreads of the P. lessonae oocytes.

\section{Comparison of $\mathrm{P}$. ridibundus and $\mathrm{P}$. lessonae lampbrush chromosome $F$}

Similar to chromosome E, lampbrush chromosome $\mathrm{F}$ of $P$. ridibundus is typically devoid of any marker structures (Figures 5a, b). Rarely, a marker loop with splicing factors can appear in the long arm of this chromosome. Lampbrush chromosome $\mathrm{F}$ of $P$. lessonae usually bears similar but more prominent marker loops at the same region (Figures 5c, d). Presence of a giant lumpy loop accumulating splicing factors is typical for the short arm of $P$. lessonae LBC F but not for the short arm of orthologous chromosome of $P$. ridibundus.

\section{Comparison of $\mathrm{P}$. ridibundus and $\mathrm{P}$. lessonae lampbrush chromosome $\mathbf{G}$}

Lampbrush chromosome $\mathrm{G}$ of $P$. ridibundus has a pair of morphologically distinct marker loops in the short arm. Giant marker loops accumulating splicing factors are situated in the long arm of this chromosome, and marker loops with normal amount of splicing factors locate near the telomeric region (Additional file 3: Figures S3i, j). As opposed to $P$. ridibundus LBC G, the ortologous lampbrush chromosome of $P$. lessonae is characterized by giant lumpy loops in the short arm near the centromere (Additional file 3: Figures S3k, l). In some preparations, we observed giant lumpy loops situated near the centromere in the long arm of chromosome G. Another pair of lumpy loops can be located close to chromosomal terminal region. All lumpy loops of $P$. lessonae LBC G accumulate pre-mRNA splicing factors.

\section{Comparison of $\mathrm{P}$. ridibundus and $\mathrm{P}$. lessonae lampbrush chromosome $\mathrm{H}$}

Differences in the morphology of LBC $\mathrm{H}$ between the two parental species are more essential. Lampbrush chromosome $\mathrm{H}$ of $P$. ridibundus bears a pair of giant fusing loops, which accumulate splicing factors, on the long arm (Figures 2a, b, f and Additional file 2: Figures S2a, b). Apart from these loops, there are two sets of marker loops in the long arm and an obvious chromosome-associated nucleolus (Figures 2b, $\mathrm{c}$ and Additional file 2: Figures S2a, b). The nucleolus has been identified by immunofluorescent staining with antibodies against its canonical components - proteins Nopp-140, No38 and fibrillarin (Figures 2b, c, e). One type of the marker loops is enriched with splicing factors, while the other one is not. In addition, we have detected two interstitial blocks of (TTAGGG) $)_{n}$ repeat or another longer repeat containing TTAGGG motif (Figures 2d, e). The first block is especially long and locates between giant fusing loops and marker loop accumulating spliceosome components, and the second one is relatively small and is located near the second group of landmarks. The orthologous lampbrush chromosome in $P$. lessonae has a somewhat different morphology (Additional file 4: Figures S4a, b). Lumpy loops and marker loops with splicing factors are located in the long arm of this chromosome, but chromosomal nucleolus organizer region remains inactive and nucleolus does not develop. In contrast with $P$. ridibundus chromosome $\mathrm{H}$, in the $\mathrm{LBC} \mathrm{H}$ of $P$. lessonae, interstitial telomeric (TTAGGG) $\mathrm{n}$ repeat or sequences containing TTAGGG repeat are present as a single block, which is located near the marker loop in the long arm (Additional file 4: Figures S4c, d).

Comparison of P. ridibundus lampbrush chromosome I and $P$. lessonae lampbrush chromosome $K$

Lampbrush chromosome I of $P$. ridibundus and chromosome $\mathrm{K}$ of $P$. lessonae differ from each other not only by comparative length, but also in the arrangement of marker structures (Figures 5e, f, g, h, 3a, b). According to specific pattern of immunostaining with mAbs K121 and Y12, $P$. ridibundus long and short arms of LBC I bear two pairs of marker loops accumulating splicing factors. In addition to these unusual loops, there is a pair of marker loops that 


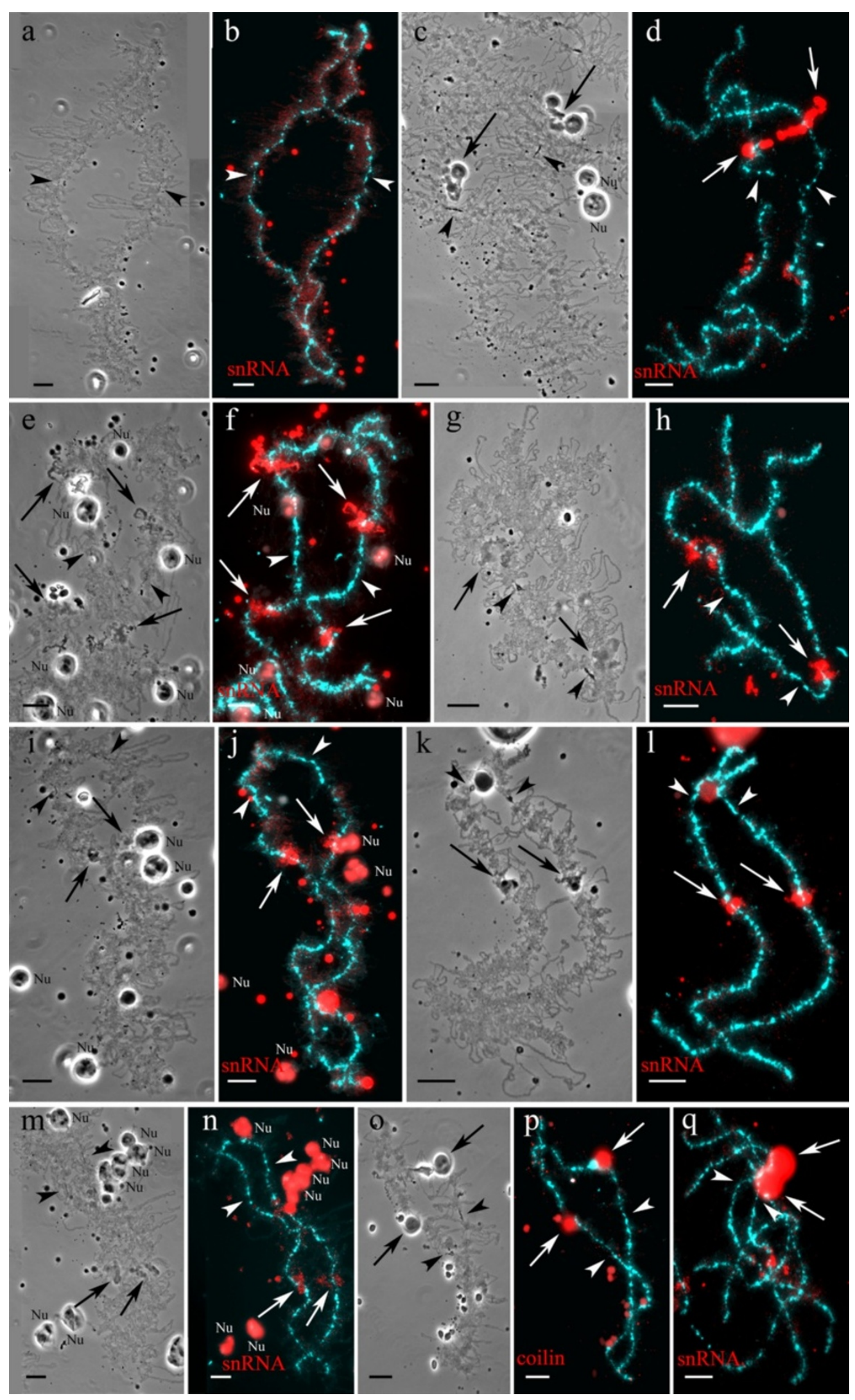

Figure 5 (See legend on next page.) 
(See figure on previous page.)

Figure 5 Comparison of $P$. ridibundus lampbrush chromosomes $F(a, b), I(e, f), K(i, j), L(m, n)$ and $P$. lessonae lampbrush

chromosomes $\mathbf{F}(\mathbf{c}, \mathbf{d}), \mathbf{K}(\mathbf{g}, \mathbf{h}), \mathbf{J}(\mathbf{k}, \mathbf{l})$ and $\mathbf{L}(\mathbf{o}, \mathbf{p}, \mathbf{q})$. Phase contrast micrographs $(\mathbf{a}, \mathbf{c}, \mathbf{e}, \mathbf{g}, \mathbf{i}, \mathbf{k}, \mathbf{m}, \mathbf{o})$ and immunofluorescent staining with antibodies against snRNA ( $\mathbf{b}, \mathbf{d}, \mathbf{f}, \mathbf{h}, \mathbf{j}, \mathbf{l}, \mathbf{n}, \mathbf{q})$ and coilin $(\mathbf{p})$. Chromosomes are counterstained with DAPI. Arrows indicate the most conspicuous marker structures on lampbrush chromosomes, arrowheads show centromeres. Nu - extrachromosomal nucleoli. Scale bars $=10 \mu \mathrm{m}$.

do not accumulate splicing factors near the terminal region of the long arm (Figures 5e, f, 3a). In its turn, P. lessonae LBC $K$ has a single pair of marker loops with higher concentration of splicing factors in its long arm. At the same time there are no long marker loops in the short or long arms of P. lessonae LBC K (Figures 5g, h, 3b).

Comparison of P. ridibundus lampbrush chromosome $J$ and P. lessonae lampbrush chromosome I

Lampbrush chromosome J of P. ridibundus and chromosome I of $P$. lessonae have almost identical centromeric index despite difference in the relative length (Tables 1 and 2) (Figure 3). Marker structures on this lampbrush chromosome in both species are weakly visible and can be absent in some oocytes. There is no much difference between the two orthologous lampbrush chromosomes in the parental species. Lampbrush chromosome $\mathrm{J}$ of $P$. ridibundus occasionally contains two pairs of small lumpy loops with a pair of long marker loop between them. All loops mapped do not accumulate splicing factors if compared with normal lateral loops (Figure 3a). Sometimes, lampbrush chromosome I of $P$. lessonae bears a pair of marker loops in a similar position, that do not accumulate pre-mRNA splicing factors (Figure $3 \mathrm{~b}$ ).

\section{Comparison of P. ridibundus lampbrush chromosome $K$ and $\mathrm{P}$. lessonae lampbrush chromosome J}

Lampbrush chromosomes $\mathrm{K}$ of $P$. ridibundus and $\mathrm{J}$ of $P$. lessonae are also characterized by similar centromeric index (Figures 5i, j, k, l). P. ridibundus LBC $\mathrm{K}$ bears a sphere close to centromere in the short arm and marker loops in the long arm. We revealed a pair of lumpy loops accumulating splicing factors in the long arm of this chromosome in all lampbrush chromosome spreads (Figures $5 \mathrm{i}, \mathrm{j})$. In the same locus of $P$. lessonae $\mathrm{LBC} \mathrm{J}$, we always identified lumpy loops accumulating snRNPs, marker loops with unusual morphology and a sphere containing pre-mRNA splicing factors and protein coilin. In addition, a pair of marker loops without higher concentration of spliceosomal components was detected in the terminal region of the short arm of $P$. lessonae LBC J (Figures 5k, l).

\section{Comparison of P. ridibundus and P. lessonae lampbrush chromosome $L$}

The long arm of lampbrush chromosome $\mathrm{L}$ of $P$. ridibundus is characterized by lumpy and marker loops enriched with splicing factors (Figures $5 \mathrm{~m}$, n). Similar lampbrush chromosome in $P$. lessonae contains lumpy loops that do not attract higher amounts of splicing factors (Figures 5o, q). In the short arm of P. lessonae LBC L, we found a large sphere containing coilin and snRNAs typical for a group of Cajal body - like bodies (Figures 5o, p).

\section{Comparison of $\mathrm{P}$. ridibundus and $\mathrm{P}$. lessonae lampbrush chromosome $M$}

Chromosome $\mathrm{M}$ in $P$. ridibundus and its ortholog in $P$. lessonae represent the smallest chromosomes at the lampbrush stage (Figure 1 and Tables 1, 2). The established pattern of distribution of splicing factors demonstrated that these chromosomes also have some distinctive features in marker structures arrangement. A pair of marker loops accumulating splicing factors forms in the long arm of $P$. ridibundus $\mathrm{LBC}$ M. At the same time P. lessonae LBC M bears large and small lumpy loops with higher concentration of splicing factors, and also long marker loops between them, which do not accumulate splicing factors in their RNP-matrix (Figure 3).

All data presented are summarized on the constructed cytological maps of all $P$. ridibundus and $P$. lessonae lampbrush chromosomes (Figures 3).

High-resolution mapping and analysis of transcriptional activity of telomere and centromere repeats

Fluorescent in situ hybridization (FISH) was applied to determine the localization of centromeric RrS1 tandem repeat in chromosomes of water frog species from the Eastern Ukraine. In both metaphase and lampbrush P. ridibundus chromosome preparations, RrS1 probe hybridized to all 13 chromosomes (Additional file 5: Figure S5a), however, chromosomes varied in the fluorescence signal intensity. Similarly, P. lessonae metaphase chromosomes showed almost the same pattern of RrS1 repeat distribution, but fluorescence signal was not detectable in one small chromosome (Additional file 5: Figure S5b). In $P$. lessonae lampbrush chromosome spreads, all chromosomes had signal of varying intensity (Additional file 6: Figure S6). In lampbrush chromosome preparations of the both species, the signal from hybridized probe was located within the centromere regions at two distinctive chromomeres as well as a constriction between them (Figures 6a, a').

Taking into account presence of lateral loops with long transcription units in centromere regions of lampbrush chromosomes of the lake frog and the pool frog, we checked for transcriptional activity of RrS1 repeat. Using DNA/(DNA+RNA) FISH we have detected transcripts of 

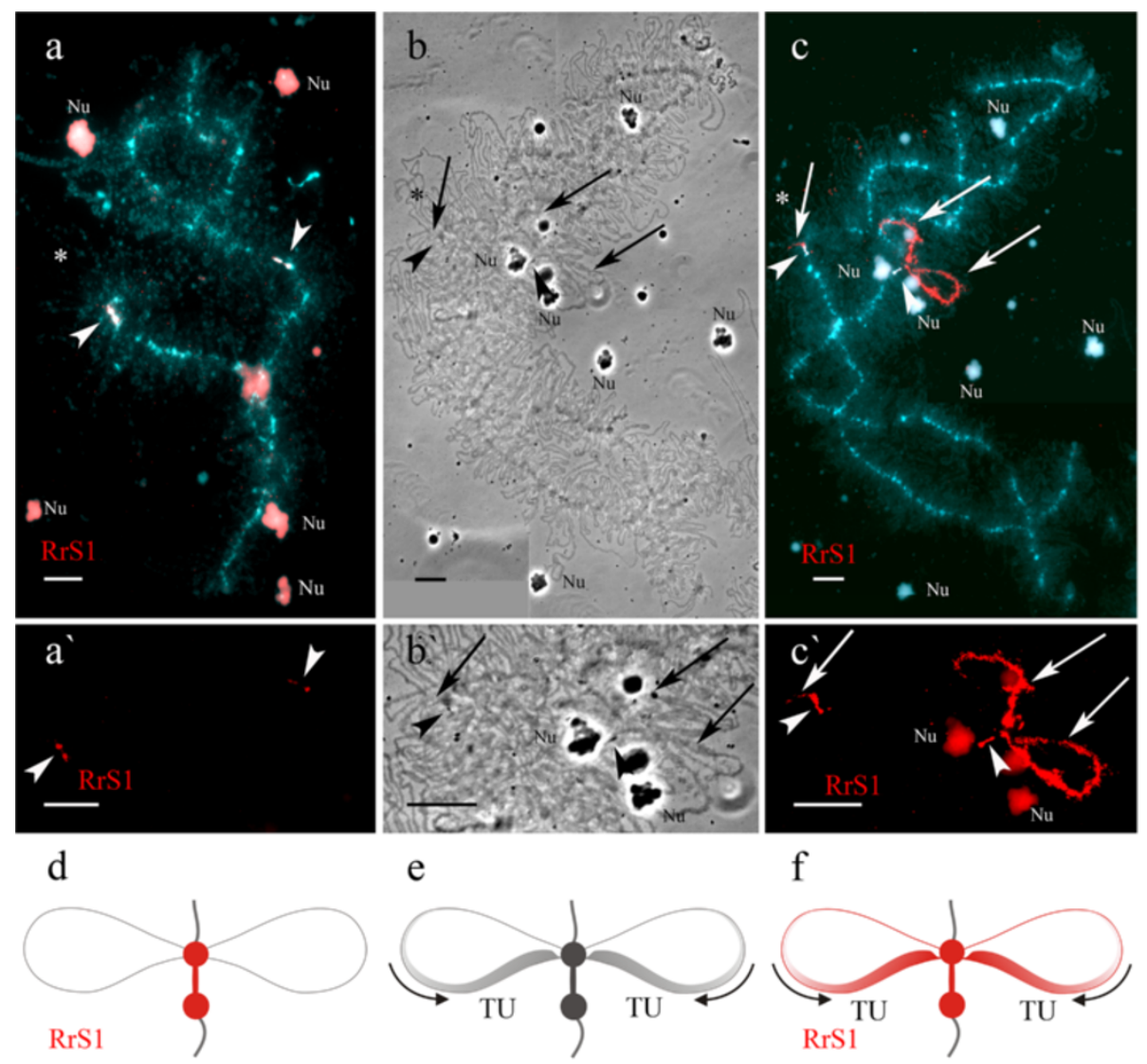

DNA/DNA hybridization

DNA/(DNA+RNA transcript) hybridization

Figure 6 Localization and transcriptional activity analysis of RrS1 repeat in centromere regions of $P$. lessonae lampbrush chromosomes. a, c. Microphotographs with DNA/DNA (a) and DNA/(DNA+RNA) (c) FISH of RrS1 repeat to lampbrush chromosomes of $P$. lessonae (red). Chromosomes are counterstained with DAPI (blue). Asterisks indicate enlarged fragments of the same chromosomes with fluorescent signal of RrS1 repeat shown on panels $\mathbf{a}^{\text {' and }} \mathbf{c}$ '. $\mathbf{d}, \mathbf{f}$. Schematic drawings of chromosomal centromere regions demonstrate the distribution of visualized DNA/DNA (d) and DNA/(DNA+RNA) (f) FISH signals (red). Transcripts of RrS1 repeat are not detectable after pretreatment with RNase A; RrS1 repeat localizes in two distinctive chromomeres in a centromere region (indicated by arrowheads) (a, a', $\mathbf{d}$ ). Without pre-treatment with RNase A hybridization signal is clearly revealed not only in centromere chromomeres but also in RNP-matrix of long lateral loops (indicated by arrows) extended from the centromere chromomeres $\left(\mathbf{c}, \mathbf{c}^{\prime}, \mathbf{f}\right)$. Circular arrows show direction of transcription $(\mathbf{e}, \mathbf{f})$. TU - transcriptional unit. b, b', e. Corresponding phase contrast micrographs $\left(\mathbf{b}, \mathbf{b}^{\prime}\right)$ and schematic drawing of a centromere region $(\mathbf{e})$. $\mathrm{Nu}$ - extrachromosomal nucleoli. Scale bars $=10 \mu \mathrm{m}$.

$\mathrm{RrS1}$ in the centromere regions of the majority of lampbrush chromosomes in both species (Figures 6b, b', c, c', e, f). In our control experiments, RNAse treatment eliminated FISH signals on the lateral loops. To confirm the specific hybridization of the labeled probe to the nascent transcripts we performed FISH according to DNA/ RNA hybridization protocol, in which chromosomal DNA was not denatured and RNAse treatment was also omitted. After DNA/RNA FISH we observed bright fluorescence signal only in the RNP matrix of lateral loops, emerging from large centromeric chromomeres. It is important to note that when chromosomes are not denatured FISH with $\mathrm{RrS1}$ repeat specifically reveals RNA molecules within transcription units on specific lateral loops of frog lampbrush chromosomes and does not label other chromosomal segments (chromomeres and other loops). Observation of DNA/RNA hybrids on RNP-matrix of lateral loops of lampbrush chromosomes during FISH experiments serves as a clear cytological evidence of satellite DNA transcription [28].

To determine the localization of TTAGGG repeats we performed DNA/DNA-hybridization with (TTAGGG) oligonucleotide. Results demonstrated that TTAGGG repeat is situated in the terminal chromomeres of all lampbrush chromosomes and in interstitial sites of chromosomes B and H (Figures 2d, 4d, d and Additional file 4: Figure S4d). In birds, telomeric repeat is transcribed during the lampbrush chromosome stage of oogenesis [29,30], but there is still lack of data on its activity in amphibian lampbrush chromosomes. Therefore, we have analyzed the 
transcriptional activity of telomeric repeat on lampbrush chromosomes of $P$. ridibundus and $P$. lessonae. DNA/RNA FISH with single stranded oligonucleotide probes to Cand G-rich strands of telomeric TTAGGG repeat allowed to discover telomere repeat transcripts on lampbrush chromosomes of both $P$. ridibundus and $P$. lessonae (Figures 7a, a', b, b'). The phenomenon was observed in all analyzed lampbrush chromosome sets from various individuals. TTAGGG repeat transcripts were localized in small caps at the ends of lampbrush chromosomes, and as opposed to $\mathrm{RrS1}$ repeat transcripts, they did not form long transcriptional units. The average size of chromosomal caps enriched with transcripts of TTAGGG repeat was about $1.5 \mu \mathrm{m}$. Notably, these telomeric repeat containing transcripts can be detected only by C-rich single stranded oligonucleotide probe (TAACCC) 5 (Figures 7b, b`) but not by the G-rich (TTAGGG) ${ }_{5}$ oligonucleotide.

\section{Discussion}

Distinctive features of lampbrush chromosomes of $P$. ridibundus and $P$. lessonae from Eastern Ukraine

Analysis of full sets of giant lampbrush chromosomes from oocytes of two parental species of the P. esculentus complex allows to study mechanisms underlying the maintenance of water frog population systems [16,25]. Here we characterized in detail various marker structures on lampbrush chromosomes of $P$. ridibundus and $P$. lessonae water frogs from Eastern Ukraine, localized nucleolus organizer region, coilin-enriched bodies, centromeres and interstitial sites of telomere repeat. These results were summarized in cytological maps for the first time constructed for all 13 lampbrush chromosomes of the both species.

Constructed maps clearly demonstrated dissimilarities in number and distribution of marker structures of
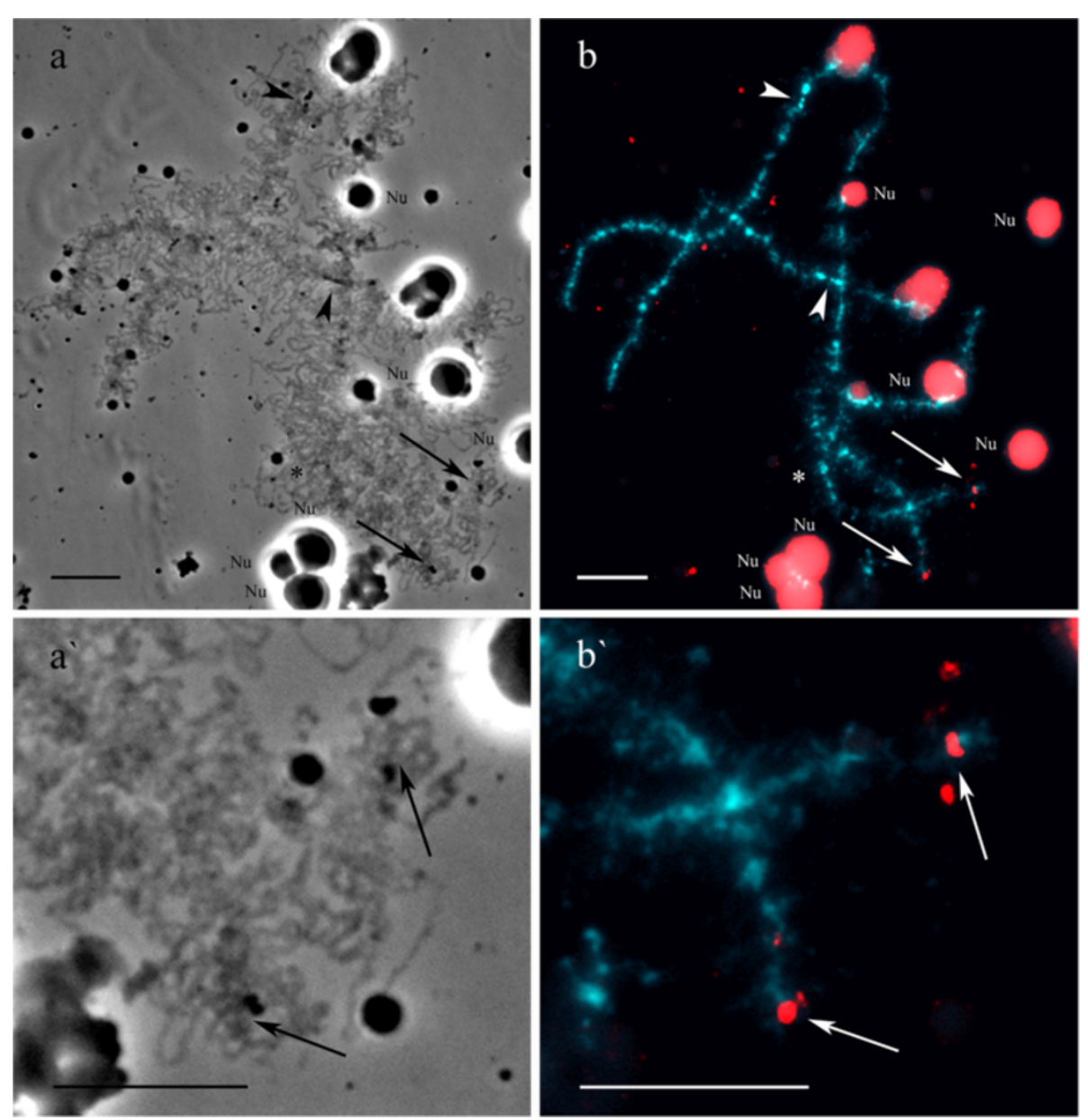

Figure 7 Detection of telomere repeat transcripts at the terminal regions of $P$. ridibundus lampbrush chromosomes. DNA/RNA FISH with (TAACCC) $)_{5}$-biotin on P. ridibundus lampbrush chromosome $E\left(\mathbf{b}, \mathbf{b}^{\mathbf{}}\right)$. (TAGGG) ${ }_{n}$-repeat transcripts are visible in small caps at the ends of lampbrush chromosomes (indicated by arrows). Asterisk indicates enlarged region of lampbrush chromosome E. Chromosomes are counterstained with DAPI. Corresponding phase contrast micrographs are shown (a, a'). Arrowheads indicate centromeres. Nu - extrachromosomal nucleoli. Scale bars $=10 \mu \mathrm{m}$. 
lampbrush chromosomes between parental species. We conclude lampbrush chromosomes of $P$. ridibundus and $P$. lessonae from Eastern Ukraine to have four main differences. Firstly, orthologous $P$. ridibundus and $P$. lessonae lampbrush chromosomes differ in positions of centromeres and comparative length, the latter could be the consequence of various levels of chromatin decondensation. Secondly, $P$. ridibundus and $P$. lessonae lampbrush chromosomes differ in number and localization of marker structures such as long marker and lumpy loops. In our opinion, the most reliable way to identify individual parental lampbrush chromosomes in karyotypes of hybrid frogs would be detection of the special loops accumulating splicing factors, because the pattern of these marker loops differs across all orthologous chromosomes. Thirdly, $P$. ridibundus and $P$. lessonae lampbrush chromosomes differ in terms of nucleolus formation. $P$. ridibundus LBC $\mathrm{H}$ bears associated nucleoli, but none of $P$. lessonae lampbrush chromosomes has active chromosomal NOR. Fourthly, $P$. ridibundus and $P$. lessonae chromosomes differ by the presence of interstitial blocks of the sequences containing (TTAGGG) $)_{\mathrm{n}}$ fragment. Presence of the (TT AGGG) ${ }_{n}$ sequence in interstitial sites allows to distinguish chromosomes $\mathrm{B}$ and $\mathrm{H}$ of $P$. ridibundus from orthologous chromosomes of $P$. lessonae.

Interpopulation similarities in the morphology of certain lampbrush chromosomes were also noticed. We compared the morphology of lampbrush chromosomes of $P$. ridibundus and $P$. lessonae from Kharkov region with the morphology of lampbrush chromosomes of these species from Poland (Table 3), the latter being described earlier by Bucci et al. [16]. We found, for instance, that localization of spheres is similar in LBCs 2 and 9 of P. ridibundus and $P$. lessonae from Poland and homologous lampbrush chromosomes of the corresponding species from Kharkov region. In addition, homology was seen in LBC 10 of P. ridibundus from Poland population and LBC $\mathrm{H}$ of P. ridibundus from Kharkov region (Table 3). Both chromosomes contain active NOR and a number of giant loops in similar loci. Moreover, localization of all marker structures in lampbrush chromosomes 2, 9 and 10 of P. ridibundus from Poland is analogous to localization of

Table 3 Comparison of lampbrush chromosomes of $P$. ridibundus from Poland and Kharkov region

\begin{tabular}{|c|c|c|c|}
\hline \multicolumn{2}{|c|}{$\begin{array}{l}\text { Lampbrush chromosomes of } P \text {. ridibundus from } \\
\text { Poland }\end{array}$} & \multicolumn{2}{|c|}{ Lampbrush chromosomes of $P$. ridibundus from Kharkov region } \\
\hline $\begin{array}{l}\text { Number of LBC according } \\
\text { to relative length }\end{array}$ & Marker structures & $\begin{array}{l}\text { Number of LBC according } \\
\text { to relative length }\end{array}$ & Marker structures \\
\hline I & long arm: s/t granule & A & $\begin{array}{l}\text { short arm: i/c long marker loop, s/t long marker loop; } \\
\text { long arm: s/t long marker loop }\end{array}$ \\
\hline$\|$ & $\begin{array}{l}\text { long arm: i/c bush like } \\
\text { loop, s/t sphere }\end{array}$ & B & short arm: i/c lumpy loop; long arm: s/t sphere \\
\hline III & & $\mathrm{D}$ & $\begin{array}{l}\text { short arm: t long marker loop, i/c lumpy loop, i/c long } \\
\text { marker loop }\end{array}$ \\
\hline IV & long arm: s/t dense like loop & C & long arm: s/t long marker loop, i/c lumpy loop \\
\hline V & & $\mathrm{E}$ & short arm: rarely i/c lumpy loop \\
\hline $\mathrm{Vl}$ & & $\mathrm{F}$ & long arm: rarely i/c long marker loop \\
\hline VII & $\begin{array}{l}\text { long arm: i/c giant } \\
\text { sructures }\end{array}$ & G & $\begin{array}{l}\text { short arm: i/c long marker loop; long arm: usually i/c } 1 \\
\text { sometimes i/c } 2 \text { long marker loops, }\end{array}$ \\
\hline VIII* & long arm: i/c bush like & $J^{*}$ & \\
\hline IX & $\begin{array}{l}\text { short arm: sphere; long } \\
\text { arm: i/c dense like }\end{array}$ & K & $\begin{array}{l}\text { short arm: sometimes sphere; long arm: usually i/c } 1 \\
\text { sometimes i/c } 2 \text { lumpy loops, }\end{array}$ \\
\hline$x$ & $\begin{array}{l}\text { long arm: i/c giant } \\
\text { structures, no }\end{array}$ & $\mathrm{H}$ & $\begin{array}{l}\text { long arm: i/c giant fusing loop, i/c } 2 \text { long marker loops, } \\
\text { no }\end{array}$ \\
\hline$X l^{*}$ & & $1^{*}$ & $\begin{array}{l}\text { short arm: i/c long marker loop; long arm: i/c } 2 \text { marker } \\
\text { loops }\end{array}$ \\
\hline$X \|^{*}$ & & $L^{*}$ & long arm: i/c lumpy loop, i/c long marker loop \\
\hline$X I I I^{*}$ & & $M^{*}$ & long arm: i/c long marker loop \\
\hline
\end{tabular}

* - The correlation between the particular lampbrush chromosomes is established only according to their relative length. Abbreviations:

$\mathrm{s} / \mathrm{t}$ - subtelomeric position of marker structure.

$\mathrm{t}$ - telomeric position of marker structure.

$\mathrm{i} / \mathrm{c}$ - intercalary position of marker structure. 
marker structures on corresponding lampbrush chromosomes of $P$. ridibundus from Greece and some other species of the genus Pelophylax [25,31].

We also observed intraspecific differences in localization of marker structures in lampbrush chromosomes of the same species from various populations. For instance, LBC 10 of $P$. lessonae from Poland population bears one attached nucleolus [16], but neither homologous LBC $\mathrm{H}$ nor any other lampbrush chromosome of $P$. lessonae from Kharkov region contains active chromosomal NOR. Additionally, we also determined dissimilarities in positions of long marker and lumpy loops. In contrast with lampbrush chromosomes of $P$. lessonae from Kharkov region, lampbrush chromosomes of $P$. lessonae from Poland were characterized by a number of giant fusing loops. Dissimilarities in localization of complex loops on lampbrush chromosomes are the consequences of intraspecies variation and polymorphism of underlying genomic sequences.

\section{Marker structures on lampbrush chromosomes of $P$. ridibundus and $P$. lessonae}

Molecular composition of marker structures on lampbrush chromosomes of $P$. ridibundus and $P$. lessonae from Kharkov region provides information on their nature. Particularly, the long marker loops developing in terminal and interstitial regions of almost all lampbrush chromosomes in both species could be classified into two types: some of them accumulate pre-mRNA splicing factors, while others do not. The transcripts synthesized on these marker loops with dense RNP-matrix are unknown since the genomes of the lake frog and the pool frog are still poorly investigated. At the same time, it can be assumed that RNA content of complex loops is most probably represented by noncoding transcripts and even transcripts of tandem repeats (reviewed in [22]). It is known for avian lampbrush chromosomes that transcripts of satellite DNA participate in formation of loops enriched with splicing factors. Particularly, DNA sequences responsible for lumpy loop formation in the long arm of chicken LBC 2 are shown to be represented by tandem "lumpy loop" 2 repeat (LL2R) [32]. Intriguingly, lumpy loops in this locus attract high amounts of splicing factors, which could be explained by presence of potential binding sites for the spliceosome components in the LL2R transcript. Another example of prominent marker structures, which we observed on lampbrush chromosomes of water frogs from the Seversky Donets River basin, are giant fusing loops that form on LBC $\mathrm{H}$ of $P$. ridibundus. One of the possible explanations implies the nascent RNA transcripts on giant fusing loops might also derive from highly repeated non-coding DNA sequences.

As far as the chromosome associated nuclear bodies are concerned, one of the most prominent examples is spherical nucleolus that forms on the long arm of $\mathrm{LBC} \mathrm{H}$ of the $P$. ridibundus. Neither orthologous chromosome nor any other lampbrush chromosomes of $P$. lessonae from Kharkov region carry attached nucleolus meaning that chromosomal NOR is completely inert at this stage of oogenesis. We have not observed any difference in NOR activity on LBC $\mathrm{H}$ throughout all seasons of the year. At the same time, generally the activity of ribosomal genes in oocyte nuclei of water frogs and other amphibians is not inhibited, since a great number of extrachromosomal nucleoli are always present in germinal vesicles of these species ([23]; our observations). Similar phenomenon of differential inactivation of main clusters of ribosomal genes on lampbrush chromosomes was described in oocytes of crested newts [28]. This selective inhibition of chromosomal NORs, but not the amplified ones that are genetically identical, can be mediated by short interfering RNA - depending and long non-coding RNA - depending mechanisms that are known to be involved into nucleolar dominance in plants and rRNA gene silencing in mammals respectively $[33,34]$.

Another type of lampbrush chromosome associated bodies is the histone locus body that is characterized by presence of coilin [35]. It was established in Xenopus that histone locus bodies form in association with clustered histone genes upon their activation [36,37]. In addition to coilin, histone locus bodies also accumulate U7 snRNA, symplekin, FLASH and other components involved into $3^{\prime}$ processing of histone pre-mRNA. Coilin- and snRNA-rich spherical structures were found in spread content of $P$. ridibundus and $P$. lessonae oocyte nuclei and were attached to specific loci on lampbrush chromosomes. Terminal granules were detected at the ends of all lampbrush chromosomes of both parental species and were shown to accumulate coilin. We demonstrated colocalization of coilin-positive granules with either terminal or interstitial sites of DNA sequences containing TTAGGG motif. In human somatic cells, coilin-positive bodies play an important role in telomerase maturation, storage and its delivery to telomeres $[38,39]$. We speculate that coilin-positive granules at the telomeres of lampbrush chromosomes can be involved into telomerase dynamics.

Interstitial blocks of TTAGGG repeat or sequences containing this repeat were detected in LBCs B and $\mathrm{H}$ of $P$. ridibundus and chromosome $\mathrm{H}$ of $P$. lessonae. Interstitial blocks of TTAGGG sequences can arise as a result of chromosomal rearrangements or telomere-telomere fusion (reviewed by [40]). TTAGGG repeat can be also included in other tandemly repetitive sequences as it was found in cases of GS repeat of chaffinch and cen 1 repeat of chicken $[41,42]$. They probably could originate via reparation of double-stranded breaks. In the subtelomeric region of P. ridibundus chromosome $\mathrm{B}$, interstitial site of TTAGGG repeat could appear as a result of unequal recombination or gene conversion event as shown for some chromosomes in human karyotype [40]. Since P. ridibundus and 
P. lessonae lampbrush chromosome $\mathrm{H}$ have similar pattern of small (TTAGGG) $)_{5}$ hybridization signal, we suppose that interstitial site of TTAGGG repeat appeared in this locus in their common ancestor. The other longer interstitial block of TTAGGG sequence in LBC $\mathrm{H}$ was found only in $P$. ridibundus karyotype, which suggests that it appeared after $P$. ridibundus and $P$. lessonae divergence.

In lampbrush chromosomes of $P$. ridibundus and P. lessonae from Kharkov region, centromeres are well identified as dense enlarged chromomeres. In contrast, in lampbrush chromosomes of $P$. lessonae from Poland, centromeres were not visible on phase contrast microphotographs [16]. The evident difference in the morphology of lampbrush centromeres supposedly depends on the amount of centromeric satellite repeats such as $\mathrm{RrS} 1$ repeat [27]. The FISH approach confirmed that all centromeres of $P$. lessonae from Kharkov region have large clusters of centromeric $\mathrm{RrS1}$ repeat if compared to centromeres of P. lessonae from Poland.

\section{Transcription of telomere and centromere repeats on} lampbrush chromosomes of $P$. ridibundus and $P$. lessonae

As it has been shown in a number of studies, termini of amphibian lampbrush chromosomes do not carry any conspicuous loops which can be analogous to terminal loops typical for avian lampbrush chromosomes (reviewed in $[22,43])$. In fact, in the very terminal transcription units of lampbrush chromosomes of chicken, turkey and pigeon, G-rich transcripts of (TTAGGG) $n$ repeat were revealed by FISH that was the first demonstration of telomere repeat transcription in vertebrates $[29,30,44]$. Here we provide, to our knowledge for the first time, evidences in favor of telomere repeat transcription during the lampbrush stage of oogenesis in amphibian species. G-rich telomeric repeat transcripts were detected on lampbrush chromosomes of water frogs as small transcription units or even tiny little caps. Using FISH of strand-specific oligonucleotides to nascent RNA transcripts we have also determined the direction of (TTAGGG) ${ }_{n}$-repeat transcription that in water frog lampbrush chromosomes proceeds to the chromosomal end. Resulting nascent transcripts of telomere repeat stay associated with terminal chromomeres for a long time.

General properties of telomere repeat transcripts on lampbrush chromosomes of water frogs and birds are the same: both amphibian and avian (TTAGGG) $)_{n}$-repeats are transcribed only from $\mathrm{C}$-rich strand in a direction towards the end of a chromosome [29, 30; our data], which could point on similarities of their functions.

Non-coding telomere repeat transcripts named TERRA (telomeric repeat-containing RNA) with the same characteristics were later described in human and mouse somatic cells and in budding yeast (reviewed by Luke and Lingner, [45]). In mammals, TERRA transcripts originating from regulated promoters consist of UUAGGG repeated sequence and a subtelomeric sequence [46]. TERRA are proposed to take part in heterochromatinization of telomere regions by RNAi mechanism and to form quadruplex structures that stabilize telomere. TERRA also might regulate replication of telomeres and inhibit telomerase activity [45]. Significance of active transcription of telomere DNA, which takes place during the lampbrush chromosomes stage of female meiosis, is largely unknown. However, we suppose that highly decondensed lampbrush chromosomes is a convenient model for studying the phenomenon of telomere repeat transcription owing to fine cytological resolution and opportunity to visualize active terminal transcription units and their RNP-content.

Intensive transcription of satellite repeats that leads to formation of extended lateral loops emerging from chromomeres is also a distinctive feature of the lampbrush stage of oogenesis $[47,48]$. Transcripts of pericentromere satellite DNA were discovered in both amphibian and avian lampbrush chromosomes several decades ago long before the breakthrough in the mechanisms of genome silencing via regulatory non-coding RNA [48-54]. Subsequently, transcripts of pericentromeric and centromeric tandem repeats were also revealed in actively proliferating somatic cells of various animals including mammals [55].

We demonstrated the transcription of satellite $\mathrm{RrS1}$ repeat in the centromere regions of lampbrush chromosomes of $P$. lessonae and $P$. ridibundus using classical and accredited approach (Figures 6c, c', f). To our knowledge, our results represent the first example of transcription of clustered centromeric satellite DNA in lampbrush chromosomes of Anura.

Phenomenon of satellite DNA transcription in lampbrush chromosomes of water frogs can be hypothetically explained by a regulatory role of maternal non-coding RNA in early stages of embryogenesis (reviewed in $[43,48])$. It is tempting to speculate that transcripts of telomeric, subtelomeric, pericentromeric and interstitial arrays of tandemly repetitive sequences synthesized during the lampbrush stage of oogenesis can be used as regulatory RNA molecules after fertilization. Such molecules could be employed for RNA-depending inhibition of transcription in definite chromosomal loci and heterochromatinization during early stage of embryogenesis providing additional mechanism for genomic stability and maintaining the integrity of species.

\section{Conclusions}

In order to characterize the lampbrush karyotypes of parental species of the $P$. esculentus complex, we have constructed detailed working maps of all lampbrush chromosomes of $P$. ridibundus and $P$. lessonae originating from Eastern Ukraine. These maps contain information about comparative location of the most conspicuous landmark 
structures classified according to their marker components and about the positions of centromere and interstitial (TTAGGG) $)_{n}$-repeat sites. Furthermore, we demonstrated the transcription of non-protein-coding centromere repeat RrS1 on lampbrush chromosomes of both $P$. ridibundus and $P$. lessonae as well as transcription of telomere repeat that proceeds in direction from subltelomere region to the chromosomal end. Constructed cytological maps and comprehensive description of landmark structures allow to identify individual chromosomes in lampbrush karyotypes of both parental species from Eastern Ukraine. The complete working maps of lampbrush chromosomes represent a useful instrument for high-resolution FISHmapping of genomic fragments. Moreover, the lampbrush chromosome maps of $P$. ridibundus and $P$. lessonae will be used for identification of genomes transmitted in female germ cells of di- and triploid hybridogenic frogs (P. esculentus) from the Seversky Donets river basin.

\section{Methods}

\section{Samples studied}

The European water frogs were sampled in the Kharkov region (Eastern Ukraine). P. ridibundus $(\mathrm{N}=8)$ individuals were collected from various localities of the Seversky Donets River basin, where they form common population systems together with hybrid frogs. $P$. lessonae $(\mathrm{N}=7)$ individuals were caught from the adjacent region, the Dnieper River basin in Krasnokutsk district, where they form population systems together with $P$. ridibundus and hybrid frogs. All manipulations with animals were carried out in accordance with relevant federal guidelines and institutional policies.

\section{DNA flow cytometry}

The amount of DNA per nucleus was measured in all $P$. ridibundus and $P$. lessonae females by flow cytometry, which was performed by using a microscope-based flow fluorimeter with mercury arc lamp as a light source. Multichannel analyzer connected with a microcomputer allowed to get DNA histograms.

After using of anesthesia, the blood was taken from the femoral vein. Blood samples were mixed with $0.1 \%$ Triton $\mathrm{X} 100,20 \mu \mathrm{g} / \mathrm{ml}$ ethidium bromide and $15 \mathrm{mM} \mathrm{MgCl}_{2}$. Measurements were made after $4-6 \mathrm{~h}\left(\right.$ at $\left.+4^{\circ} \mathrm{C}\right)$. To estimate genome size of specimens under study their samples were compared with reference standard samples of Rana temporaria (St. Petersburg region), and then additionally with samples of male domestic mouse (Mus musculus; spleenocytes, C57B1 line, $6.8 \mathrm{pg}$, according to Bianchi et al. [56]). Nuclear DNA content was converted from relative unit to histograms using a formula: DNA content $=($ samples mean peak)/ (reference standard peak) $\times$ (reference standard genome size) $[57,58]$.

\section{Lampbrush chromosome isolation}

Spread preparations of $P$. ridibundus and $P$. lessonae oocyte nucleus contents were made according to procedure described by Callan et al. [59] with modifications suggested by Gall et al. [60]. Oocytes of $0.5-1.5 \mathrm{~mm}$ in diameter were obtained from non-stimulated females by manual dissection of ovary fragments within the OR2 saline $(82.5 \mathrm{mM}$ $\mathrm{NaCl}, 2.5 \mathrm{mM} \mathrm{KCl}, 1 \mathrm{mM} \mathrm{MgCl}, 1 \mathrm{mM} \mathrm{CaCl} 2,1 \mathrm{mM}$ $\mathrm{Na}_{2} \mathrm{HPO}_{4}, 5 \mathrm{mM}$ HEPES (4-(2-hydroxyethyl)-1-piperazi neethanesulfonic acid); $\mathrm{pH}$ 7.4). Nuclei were then microsurgically isolated from oocytes by jeweler forceps in the isolation medium " $5: 1$ " ( $83 \mathrm{mM} \mathrm{KCl,} 17 \mathrm{mM} \mathrm{NaCl}, 6.5$ $\mathrm{mM} \mathrm{Na} \mathrm{HPO}_{4}, 3.5 \mathrm{mM} \mathrm{KH_{2 }} \mathrm{PO}_{4}, 1 \mathrm{mM} \mathrm{MgCl}, 1 \mathrm{mM}$ DTT (dithiothreitol); pH 7.0-7.2). Nuclear envelopes were removed in one-fourth strength " $5: 1$ " medium with the addition of $0.1 \%$ paraformaldehyde and $0.01 \% 1 \mathrm{M} \mathrm{MgCl}_{2}$ in a chambers attached to a specimen slide. All microsurgical procedures were performed under the observation at Leica MZ16 stereomicroscope. Then slide preparations of oocyte nuclei contents were centrifuged for $30 \mathrm{~min}$ at $+4^{\circ} \mathrm{C}, 4000 \mathrm{rpm}$. After a brief fixation (for $30 \mathrm{~min}$ ) in $2 \%$ paraformaldehyde in $1 \times$ phosphate buffered saline (PBS), preparations were post-fixed in $70 \%$ ethanol overnight (at $+4^{\circ} \mathrm{C}$ ). Preparations were not dried before immunostaining. Lampbrush chromosome maps were constructed as described in [18]. All marker structures on lampbrush chromosomes were assorted according to classification suggested by Callan [18].

\section{Preparation of mitotic and meiotic metaphase chromosomes}

Mitotic and meiotic metaphase chromosomes were obtained from intestine and testes. Each individual was injected with $0.2-0.5 \mathrm{ml}$ of a $0.3 \%$ solution of colchicine (48 hr prior to biopsy for intestinal tissue, $24 \mathrm{hr}$ for testicular tissue). Tissue fragments were incubated in hypotonical solution for 20 minutes, then for 20 minutes in $45 \%$ acetic acid, and kept in 3:1 ethanol-glacial acetic acid until slide preparation. The cell suspension was resuspended onto specimen slides. The slides were dried and stored at $-20^{\circ} \mathrm{C}$ before use.

\section{Immunofluorescent staining of germinal vesicle spreads}

For immunostaining of frog oocyte nucleus content preparations we used the following mouse monoclonal antibodies $(\mathrm{mAb})$ and rabbit polyclonal antibodies $(\mathrm{pAb}): \mathrm{mAb}$ No-185 against No38 protein [61], mAb No114 against Nopp140 protein [62], mAb 17c12 against fibrillarin [63], mAb 38F3 against fibrillarin (Santa Cruz Biotechnology), mAb K121 against 2,2,7-trimethyl guanosine cap (Santa Cruz Biotechnology), mAb Y12 against symmetrical dimethylarginine [64] and pAb R288 against C terminal domain of coilin [65]. Lampbrush chromosome spreads were incubated for 5 minutes in 70\%, 50\%, 30\% ethanol, and in 
PBS with $0.01 \%$ Tween-20 and then were blocked in PBS containing $1 \%$ blocking reagent (Roche) for $1 \mathrm{~h}$ at RT, then incubated with primary antibody (dilutions as recommended by authors or manufacturers) for $1 \mathrm{~h}$ at RT. Slides were washed in PBS, $0.05 \%$ Tween-20 and incubated in corresponding secondary antibody or combination of antibodies (Cy3-conjugated goat anti-rabbit IgG (Jackson ImmunoResearch Laboratories), Alexa-488-conjugated goat anti-mouse IgG, Cy3-conjugated goat anti-mouse IgG and IgM (Molecular Probes)) for $1 \mathrm{~h}$ at RT. Slides were washed in PBS, $0.05 \%$ Tween-20 and mounted in DABCO antifade solution containing $1 \mathrm{mg} / \mathrm{ml}$ DAPI.

\section{Fluorescence in situ hybridization}

A PCR product amplified from $P$. lessonae genomic DNA with following primers specific to RrS1 highly repetitive centromeric sequence [27] was used as a probe for fluorescence in situ hybridization (FISH):

\section{F 5'-AAGCCGATTTTAGACAAGATTGC-3'; R 5'-GGCCTTTGGTTACCAAATGC-3'}

The probe was labelled with biotin-16-dUTP (Roche) by PCR with the same primers at the standard conditions. The labelled probes were dissolved to a final concentration of $10-50 \mathrm{ng} / \mu \mathrm{l}$ in a hybridization buffer $(50 \%$ formamide, $2 \times \mathrm{SSC}$ ( $3 \mathrm{M}$ sodium chloride and $300 \mathrm{mM}$ trisodium citrate), $10 \%$ dextran sulphate) with a 50 -fold excess of salmon sperm DNA. In case of hybridization to lampbrush chromosomes, three variants of FISH were carried out: (1) DNA/DNA hybridization, with pre-treatment with RNase A; (2) DNA/(DNA+RNA) hybridization and (3) DNA/ RNA hybridization, without RNase A treatment. In the first two variants, lampbrush chromosomes were denatured at $81.5^{\circ} \mathrm{C}$ for $5 \mathrm{~min}$; in the third one chromosomal DNA was not denatured. Then slides were incubated with probe in hybridization buffer overnight at $37^{\circ} \mathrm{C}$. After hybridization, slides were washed three times in $0.2 \times \mathrm{SSC}$ at $60^{\circ} \mathrm{C}$ and once in $2 \times \mathrm{SSC}$ at $42^{\circ} \mathrm{C}$. Biotin was detected by avidin conjugated with $\mathrm{Cy} 3$ (Jackson ImmunoResearch Laboratories). All preparations after FISH were mounted in antifade solution containing $1 \mathrm{mg} / \mathrm{ml}$ DAPI.

In case of FISH to metaphase chromosomes, chromosome preparations were pre-treated with RNase A $(100-200 \mu \mathrm{g} / \mathrm{ml})$, pepsin $(0.01 \%$ in $0.01 \mathrm{~N} \mathrm{HCl})$ and then post-fixed in formaldehyde (1\% in PBS, $50 \mathrm{mM}$ $\mathrm{MgCl}_{2}$ ). DNA/DNA hybridization was performed as described above.

DNA/RNA and DNA/(DNA+RNA) FISH with telomeric probe was preformed on lampbrush chromosomes at softer conditions as described by Solovei and co-authors [29]. Biotin conjugated telomeric single-stranded oligonucleotide probes $(\text { TAACCC })_{5}$ and (TTAGGG) $)_{5}$ were used for hybridization. The hybridization mixture contained $40 \%$ formamide, $2.4 \times \mathrm{SSC}$, and $12 \%$ dextran sulphate, $5 \mathrm{ng} / \mu \mathrm{l}$ labeled probe and 10-50-fold excess of tRNA. For DNA/ RNA hybridization chromosomes were not denatured. Hybridization was performed at room temperature for 12-18 h. After hybridization, slides were washed three times in $2 \times \mathrm{SSC}$ at $42^{\circ} \mathrm{C}$. Biotin was detected by avidin conjugated with Cy3 (Jackson ImmunoResearch Laboratories). Chromosomes were counterstained with $1 \mathrm{mg} / \mathrm{ml}$ DAPI.

\section{Wide-field microscopy}

Preparations of oocyte nuclei contents were examined using Leica fluorescence microscope DM4000 equipped with a monochrome digital camera DFC350 FX and appropriate filter cubes (Leica Wetzlar GmbH, Germany). Images were taken with $40 \times / 1$ and $100 \times / 1$.30 oil immersion objectives at RT. Leica CW 4000 FISH software was used for acquisition and processing the multicolor images.

\section{Additional files}

Additional file 1: Figure S1. Full set of lampbrush chromosomes from P. ridibundus oocytes. Immunofluorescent staining with antibodies K121 against TMG-cap of snRNAs reveals enriched marker loops. Chromosomes are counterstained with DAPI. Corresponding phase contrast micrographs are shown at Figure 1. Nu - extrachromosomal and chromosome associated nucleoli. Arrows indicate the most conspicuous marker loops. Scale bar $=50 \mu \mathrm{m}$.

Additional file 2: Figure S2. Construction of cytological lampbrush chromosome map on example of $P$. ridibundus lampbrush chromosome H. b. Morphology of lampbrush chromosome H. Giant fusing loops, associated nucleoli and two pairs of marker loops are the most conspicuous marker structures. Dotted lines indicate two marker structures on lampbrush chromosomes, arrowheads show centromeres. Phase contrast micrograph. a. Plotting marker structures on the working chromosome map according to their relative position on lampbrush chromosome. $\mathrm{Nu}$ - extrachromosomal and chromosome associated nucleoli. Scale bars $=10 \mu \mathrm{m}$.

Additional file 3: Figure S3. Comparison of $P$. ridibundus lampbrush chromosome C $(\mathbf{a}, \mathbf{b}), \mathrm{D}(\mathbf{e}, \mathbf{f}), \mathrm{G}(\mathbf{i}, \mathbf{j})$ and $P$. lessonae lampbrush chromosome $\mathrm{D}(\mathbf{c}, \mathbf{d}), \mathrm{C}(\mathbf{g}, \mathbf{h})$ and $\mathrm{G}(\mathbf{k}, \mathbf{l})$. Phase contrast micrographs $(\mathbf{a}, \mathbf{c}, \mathbf{e}, \mathbf{g}, \mathbf{i}, \mathbf{k})$ and immunofluorescent staining with antibodies against TMG-cap of snRNAs $(\mathbf{b}, \mathbf{d}, \mathbf{f}, \mathbf{h}, \mathbf{j}, \mathbf{l})$. Chromosomes are counterstained with DAPI. Arrows indicate the most conspicuous marker structures on lampbrush chromosomes, arrowheads show centromeres. Nu - extrachromosomal nucleoli. Scale bars $=10 \mu \mathrm{m}$.

Additional file 4: Figure S4. Chromosome $H$ of $P$. lessonae. Phase contrast micrograph (a), immunofluorescent staining with antibodies against TMG-cap of snRNAs (b), coilin (c) and FISH with (TAACCC) s-biotin $^{-}$ oligonucleotide (d). Chromosomes are counterstained with DAPI. Arrows indicate lumpy and long marker loops in long arm of chromosome $\mathrm{H}$ of P. lessonae $(\mathbf{a}, \mathbf{b})$. Terminal and interstitial blocks of (TTAGGG) repeat (indicated by arrows) in $P$. lessonae lampbrush chromosome $\mathrm{H}$ (d). Arrows show coilin-positive granules in telomere regions and in interstitial sites corresponding to chromomeres containing (TTAGGG)-repeat (c). Arrowheads show centromeres. Nu - extrachromosomal nucleoli. Scale bars $=10 \mu \mathrm{m}$.

Additional file 5: Figure S5. RrS1 centromere repeat mapping in metaphase chromosome preparations of both parental frog species from the Eastern Ukraine. FISH with RrS1 repeat in metaphase chromosomes of $P$. ridibundus (a) and $P$. lessonae (b). Arrows indicate clusters of RrS1 
repeat in metaphase chromosomes of $P$. ridibundus and $P$. lessonae. Chromosomes are counterstained with DAPI. Scale bars $=10 \mu \mathrm{m}$.

Additional file 6: Figure S6. RrS1 centromere repeat mapping in lampbrush chromosomes of $P$. lessonae. a. FISH of RrS1 repeat to lampbrush chromosomes of $P$. lessonae. Clusters of RrS1 repeat of various size localize in centromere regions (shown by arrowheads) of all chromosomes. Asterisks indicate enlarged fragments of lampbrush chromosomes. Scale bar $=50 \mu \mathrm{m}$. b, c, d. Fragments of chromosomes with conspicuous cluster of $\mathrm{RrS1}$ repeat in a centromere region. $\mathrm{Nu}-$ extrachromosomal nucleoli. Chromosomes are counterstained with DAPI. Scale bars $=10 \mu \mathrm{m}$.

\section{Abbreviations}

DAPI: 4',6-diamidino-2-phenylindole; FISH: Fluorescence in situ hybridization; LBC: Lampbrush chromosome; LL2R: "Lumpy loop" 2 repeat; mAb: Monoclonal antibodies; NOR: Nucleolus organizer region; pAb: Polyclonal antibodies; PBS: Phosphate buffered saline; PCR: Polymerase chain reaction; RNP: Ribonucleoprotein; RrS1: Rana ridibunda sequence 1; SnRNA: Small nuclear RNA; SSC: Saline-sodium citrate buffer;

TERRA: Noncoding telomeric repeat-containing RNA; TMG cap: 2,2,

7-trimethylguanosine cap.

\section{Competing interests}

The authors declare that they have no competing interests.

\section{Authors' contributions}

DD and DS collected the samples. DD carried out the lampbrush chromosome isolation, performed immunofluorescent assays and FISH experiments, constructed the cytological maps and drafted the manuscript. AK analyzed the micrographs, verified the cytological maps, participated in the design of the study and its coordination and revised the manuscript. JR performed the DNA flow cytometry experiments. SL prepared metaphase chromosomes and participated in species identification. GM participated in lampbrush chromosome isolation. LB helped to discuss the obtained results. AS participated in the design of the study. All authors read and approved the final version of the manuscript.

\section{Acknowledgments}

We are grateful to O. V. Korshunov (V. N. Karazin Kharkiv National University, Ukraine) for the field assistance and A. V. Maslova (Saint-Petersburg State University, Russia) and R. A. Pasynkova (Institute of Cytology, RAN) for technical assistance. This investigation was supported by research Grant of the President of Russian Federation (project \# 4385.2012.4) and Federal Grant-in-Aid Program «Human Capital for Science and Education in Innovative Russia»" "GC \# 8122 from 23.07.2012) and RFBR grant 12-04-01807. The work of SL was partially funded by grants RFBR 12-04-01277 and MCB-N22n. The authors acknowledge Saint-Petersburg State University for a research grant \# 1.38.66.2011 and the Core Facility 'CHROMAS' (Saint-Petersburg State University) for technical support.

\section{Author details}

'Saint-Petersburg State University, Oranienbaumskoie sch. 2, Stary Peterhof, Saint-Petersburg 198504, Russia. ${ }^{2}$ Department of Ecology and Genetic, Population Biology and Conservation Biology, Evolutionary Biology Centre, Uppsala University, EBC Norbyvägen 18 D, Uppsala 75236, Sweden. ${ }^{3}$ V.N. Karazin Kharkiv National University, Svobody Sq. 4, Kharkiv 61022, Ukraine. ${ }^{4}$ Institute of Cytology Russian Academy of Sciences, Tikhoretsky pr. 4, St. Petersburg 194064, Russia. ${ }^{5}$ Zoological Institute, Russian Academy of Sciences, Universitetskaia nab.1, St. Petersburg 199034, Russia.

Received: 3 January 2013 Accepted: 4 April 2013

Published: 16 April 2013

\section{References}

1. Johnson NA: Direct selection for reproductive isolation: the Wallace effect and reinforcement. In Natural Selection and Beyond: The Intellectual Legacy of Alfred Russel Wallace. Edited by Smith CH, Beccaloni GW. Oxford: Oxford University Press; 2008:114-124

2. Borkin LY, Darevsky IS: Reticulate (hybridogenus) speciation in vertebrata. J Obsh Biol 1980, 41:485-506
3. Barton NH: The role of hybridization in evolution. Mol Ecol 2001, 10:551-568.

4. Alves MJ, Coelho MM, Collares-Pereira MJ: Evolution in action through hybridization and polyploidy in an Iberian fresh water fish: a genetic review. Genetica 2001, 111:375-385.

5. Stöck M, Steinlein C, Lamatsch DK, Schartl M, Schmid M: Multiple origins of tetraploid taxa in the Eurasian Bufo viridis subgroup. Genetica 2005, 124:255-272.

6. Plötner J: Die westpaläarktichen Wasserfrösche. Bielefeld: Laurenti-Verlag; 2005.

7. Berger $L:$ Some characteristics of the crosses within Rana esculenta complex in postlarval development. Ann Zool Fenn 1970, 27:374-416.

8. Tunner HG: Das albumin und andere bluteiweiße bei Rana ridibunda Pallas, Rana lessonae Camerano, Rana esculenta Linné und deren hybriden. Z zool Syst Evol 1973, 11:219-233.

9. Berger $\mathrm{L}:$ On the origin of genetic systems in European water frog hybrids. Zool Poloniae 1990, 35:5-27.

10. Borkin $\sqcup$, Litvinchuk SN, Mannapova El, Pestov MV, Rosanov JM: The distribution of green frogs (Rana esculenta complex) in Nizhny Novgorod province, central European Russia. Russ J Herpetol 2003, 9(3):195-208.

11. Borkin $\sqcup$, Korshunov AV, Lada GA, Litvinchuk SN, Rosanov JM, Shabanov DA, Zinenko Al: Mass occurrence of polyploid green frogs (Rana esculenta complex) in eastern Ukraine. Russ J Herpetol 2004, 11:194-213.

12. Shabanov DA, Zinenko Al, Korshunov AV, Kravchenko MO, Mazepa GO: The study of population systems of green frogs (Rana esculenta complex) in Kharkov region: history, modern condition and prospects. Kharkov Nat University J 2006, 3(729):208-220.

13. Korshunov AV: Ecological patterns of biotopic distribution of Pelophylax esculentus complex in Kharkiv region. Kharkov Nat University J 2009, 8(828):48-57.

14. Heppich S: Hybridogenesis in Rana esculenta: C-band karyotypes of Rana ridibunda, Rana lessonae and Rana esculenta. Z zool Syst Evol 1978, 16:27-39.

15. Heppich S, Tunner HG, Greilhuber J: Premeiotic chromosome doubling after genome elemination during spermatogenesis of the species hybrid Rana esculenta. Theor Appl Genet 1982, 61:101-104.

16. Bucci S, Ragghianti M, Mancino G, Berger L, Hotz H, Uzzell T: Lampbrush and mitotic chromosomes of the hemiclonally reproducing hybrid Rana esculenta and its parental species. J Exp Zool Suppl 1990, 255:37-56.

17. Tunner HG, Heppich-Tunner S: Genome exclusion and two strategies of chromosome duplication in oogenesis of a hybrid frog. Naturwissenschaften 1991, 78:32-24. 32-34.

18. Callan HG: Lampbrush Chromosomes. London: Springer-Verlag; 1986.

19. Macgregor HC, Sessions SK, Arntzen JW: An integrative analysis of phylogenetic relationships among newts of the genus Triturus (family Salamandridae), using comparative biochemistry, cytogenetics and reproductive interactions. J Evolution Biol 1990, 3:329-373.

20. Macgregor HC: Lampbrush chromosomes and gene utilization in meiotic prophase. Symp Soc Exp Biol 1984, 38:333-347.

21. Gaginskaya ER: The lampbrush chromosomes in the amphibian oocytes. Tsitologiia 1989, 31:1267-1291.

22. Morgan GT: Lampbrush chromosomes and associated bodies: new insights into principles of nuclear structure and function. Chromosome Res 2002, 10:177-200.

23. Gall JG, Wu Z, Murphy C, Gao H: Structure in the amphibian germinal vesicle. Exp Cell Res 2004, 296:28-34.

24. Graf JD, Müller WP: Experimental gynogenesis provides evidence of hybridogenetic reproduction in the Rana esculenta complex. Experientia 1979, 35:1574-1576.

25. Guerrini F, Bucci S, Ragghianti M, Mancino G, Hotz H, Uzzell T, Berger L: Genomes of two water frog species resist germ line exclusion in interspecies hybrids. J Exp Zool 1997, 279:163-176.

26. Vinogradov $A E$, Borkin $\sqcup$, Günther R, Rosanov JM: Genome elimination in diploid and triploid Rana esculenta males: cytological evidence from DNA flow cytometry. Genome 1990, 33:619-627.

27. Ragghianti M, Guerrini F, Bucci S, Mancino G, Hotz H, Uzzell T, Guex GD: Molecular characterization of a centromeric satellite DNA in the hemiclonal hybrid frog Rana esculenta and parental species. Chromosome Res 1995, 3(8): 497-506.

28. Macgregor $\mathrm{HC}$, Varley JM, Morgan GT: The transcription of satellite and ribosomal DNA sequences on lampbrush chromosomes of crested newts. In International Cell Biology. Edited by Schweiger HD. Berlin: Heidelberg: SpringerVerlag; 1981:33-46. 
29. Solovei I, Gaginskaya ER, Macgregor HC: The arrangement and transcription of telomere DNA sequences at the ends of lampbrush chromosomes of birds. Chromosome Res 1994, 2:460-470

30. Solovei I, Macgregor HC, Gaginskaya E: Specifically terminal clusters of telomere DNA sequences are transcribed from the C-rich strand on chicken lampbrush chromosomes. In Proceedings of Kew Chromosome Conference N. Edited by Brandham PF, Bennett MD. Richmond (United Kingdom): Royal Botanic Gardens (KRBG); 1995:323-330.

31. Marracci S, Michelotti V, Gaston-Denis G, Hotz H, Uzzell T, Ragghianti M: RrS1-like sequences of water frogs from central Europe and around the Aegean Sea: chromosomal organization, evolution, possible function. J Mol Evol 2011, 72:368-382.

32. Krasikova A, Vasilevskaya E, Gaginskaya E: Chicken lampbrush chromosomes: transcription of tandemly repetitive DNA sequences. Russ J Genet 2010, 46:1173-1177.

33. Preuss SB, Costa-Nunes $P$, Tucker S, Pontes $O$, Lawrence RJ, Mosher R, Kasschau KD, Carrington JC, Baulcombe DC, Viegas W, Pikaard CS: Multimegabase silencing in nucleolar dominance involves siRNAdirected DNA methylation and specific methylcytosine-binding proteins. Mol Cell 2008, 32:673-684.

34. Tucker S, Vitins A, Pikaard CS: Nucleolar dominance and ribosomal RNA gene silencing. Curr Opin Cell Biol 2010, 22:351-356.

35. Nizami ZF, Deryusheva S, Gall JG: Cajal bodies and histone locus bodies in Drosophila and Xenopus. Cold Spring Harb Sym 2010, 75:313-320.

36. Gall JG, Stephenson EC, Erba HP, Diaz MO, Barsacchi-Pilone G: Histone genes are located at the sphere loci of newt lampbrush chromosomes. Chromosoma 1981, 84:159-171.

37. Callan HG, Gall JG, Murphy C: Histone genes are located at the sphere loci of Xenopus lampbrush chromosomes. Chromosoma 1991, 101:245-251.

38. Tomlinson RL, Ziegler TD, Supakorndej T, Terns RM, Terns MP: Cell cycleregulated trafficking of human telomerase to telomeres. Mol Biol Cell 2006, 17:955-965.

39. Venteicher AS, Abreu EB, Meng Z, McCann KE, Terns RM, Veenstra TD, Terns MP, Artandi SE: A human telomerase holoenzyme protein required for Cajal body localization and telomere synthesis. Science 2009, 323:644-648.

40. Kah Wai Lin JY: Endings in the middle: Current knowledge of interstitial telomeric sequences. Mutat Res 2007, 658:95-110.

41. Derjusheva S, Kurganova A, Habermann F, Gaginskaya E: High chromosome conservation detected by comparative chromosome painting in chicken, pigeon and passerine birds. Chromosome Res 2004, 12:715-723.

42. Krasikova A, Fukagawa T, Zlotina A: High-resolution mapping and transcriptional activity analysis of chicken centromere sequences on giant lampbrush chromosomes. Chromosome Res 2012, 20:995-1008 doi:10.1007/ s10577-012-9321-0.

43. Gaginskaya E, Kulikova T, Krasikova A: Avian lampbrush chromosomes: a powerful tool for exploration of genome expression. Cytogenet Genome Res 2009, 124:251-267.

44. Swanberg SE, O'Hare $\mathrm{TH}$, Robb EA, Robinson CM, Chang H, Delany ME: Telomere biology of the chicken: a model for aging research. Exp Gerontol 2010, 45:647-654.

45. Luke B, Lingner J: TERRA: telomeric repeat-containing RNA. EMBO J 2009, 28:2503-2510.

46. Farnung BO, Giulotto E, Azzalin CM: Promoting transcription of chromosome ends. Transcription 2010, 1:140-143.

47. Varley JM, Macgregor HC, Erba HP: Satellite DNA is transcribed on lampbrush chromosomes. Nature 1980, 283:686-688.

48. Krasikova A, Gaginskaya E: Organization of centromere regions of chromosomes in the lampbrush phase. Tsitologiia 2010, 52(7):515-533.

49. Diaz MO, Barsacchi-Pilone G, Mahon KA, Gall JG: Transcripts from both strands of a satellite DNA occur on lampbrush chromosome loops of the newt Notophthalmus. Cell 1981, 24:649-659.

50. Baldwin L, Macgregor HC: Centromeric satellite DNA in the newt Triturus cristatus karelinii and related species: its distribution and transcription on lampbrush chromosomes. Chromosoma 1985, 92:100-107.

51. Barsacchi-Pilone G, Batistoni R, Andronico F, Vitelli L, Nardi I: Heterochromatic DNA in Triturus (Amphibia, Urodela). I. A satellite DNA component of the pericentric C-bands. Chromosoma 1986, 93:435-446.

52. Solovei I, Joffe BI, Gaginskaya ER, Macgregor HC: Transcription on lampbrush chromosomes of a centromerically localized highly repeated DNA in pigeon (Columba) relates to sequence arrangement. Chromosome Res 1996, 4:588-603.
53. Krasikova A, Deryusheva S, Galkina S, Kurganova A, Evteev A, Gaginskaya E: On the positions of centromeres in chicken lampbrush chromosomes. Chromosome Res 2006, 14:777-789.

54. Deryusheva S, Krasikova A, Kulikova T, Gaginskaya E: Tandem 41-bp repeats in chicken and Japanese quail genomes: FISH mapping and transcription analysis on lampbrush chromosomes. Chromosoma 2007, 116:519-530.

55. Eymery A, Callanan M, Vourc'h C: The secret message of heterochromatin: new insights into the mechanisms and function of centromeric and pericentric repeat sequence transcription. Int J Dev Biol 2009, 53:259-268.

56. Bianchi NO, Redi C, Garagna C, Capanna E, Manfredi-Romanini MG: Evolution of the genome size in Akodon (Rodentia, Cricetidae). J Mol Evol 1983, 19:362-370.

57. Borkin $\sqcup$, Eremchenko VK, Helfenberger N, Panfilov AM, Rosanov JM: On the distribution of diploid, triploid, and tetraploid green toads (Bufo viridis complex) in south-eastern Kazakhstan. Russ J Herpetol 2001, 8(1):45-53.

58. Litvinchuk SN, Borkin $\sqcup$, Rosanov JM: Intra- and interspecific genome size variation in hynobiid salamanders of Russia and Kazakhstan: determination by flow cytometry. Asiat Herpetol Res 2004, 10:282-294.

59. Callan HG, Gall JG, Berg CA: The lampbrush chromosomes of Xenopus laevis: preparation, identification and distribution of 5SDNA sequences. Chromosoma 1987, 95:236-250

60. Gall JG, Murphy C, Callan HG, Wu ZA: Lampbrush chromosomes. Method Cell Biol 1991, 36:149-166.

61. Schmidt-Zachmann MS, Hugle-Dorr B, Franke WW: A constitutive nucleolar protein identified as a member of the nucleoplasmin family. EMBO J 1987, 6:1881-1890

62. Schmidt-Zachmann MS, Hugle B, Scheer U, Franke WW: Identification and localization of a novel nucleolar protein of high molecular weight by a monoclonal antibody. Exp Cell Res 1984, 153:327-346.

63. Pollard KM, Lee DK, Casiano CA, Bluthner M, Johnston MM, Tan EM: The autoimmunity-inducing xenobiotic mercury interacts with the autoantigen fibrillarin and modifies its molecular and antigenic properties. J Immunol 1997, 158(7):3521-3528

64. Lerner EA, Lerner MR, Janeway CA, Steitz JA: Monoclonal antibodies to nucleic acid-contairdng cellular constituents: Probes for molecular biology and autoimmune disease. P Natl Acad Sci USA 1981, 78:2737-2741.

65. Andrade LE, Chan EK, Raska I, Peebles CL, Roos G, Tan EM: Human autoantibody to a novel protein of the nuclear coiled body: immunological characterization and cDNA cloning of p80-coilin. J Exp Med 1991, 173:1407-19.

doi:10.1186/1471-2156-14-26

Cite this article as: Dedukh et al:: Cytological maps of lampbrush chromosomes of European water frogs (Pelophylax esculentus complex) from the Eastern Ukraine. BMC Genetics 2013 14:26.

\section{Submit your next manuscript to BioMed Central and take full advantage of:}

- Convenient online submission

- Thorough peer review

- No space constraints or color figure charges

- Immediate publication on acceptance

- Inclusion in PubMed, CAS, Scopus and Google Scholar

- Research which is freely available for redistribution

Submit your manuscript at www.biomedcentral.com/submit
C BioMed Central 